US Army Corps of Engineers ${ }_{\circledast}$

Engineer Research and Development Center

\title{
Sedimentation Response to Wharf Expansion Plans for the Columbus Street Terminal, Charleston, South Carolina
}

Allen M. Teeter, Gary L. Brown, Christopher J. Callegan, Darla C. McVan, and M. Soraya Sarruff 
The contents of this report are not to be used for advertising, publication, or promotional purposes. Citation of trade names does not constitute an official endorsement or approval of the use of such commercial products.

The findings of this report are not to be construed as an official Department of the Army position, unless so designated by other authorized documents. 


\section{Sedimentation Response to Wharf Expansion Plans for the Columbus Street Terminal, Charleston, South Carolina}

by $\quad$ Allen M. Teeter, Gary L. Brown, Christopher J. Callegan, Darla C. McVan, M. Soraya Sarruff

Coastal and Hydraulics Laboratory

U.S. Army Engineer Research and Development Center 3909 Halls Ferry Road

Vicksburg, MS 39180-6199

Final report

Approved for public release; distribution is unlimited 


\section{Engineer Research and Development Center Cataloging-in-Publication Data}

Sedimentation response to wharf expansion plans for the Columbus Street Terminal, Charleston, South Carolina / by Allen M. Teeter ... [et al.] ;prepared for South Carolina State Ports Authority. 45 p. : ill. ; 28 cm. -- (ERDC/CHL; TR-00-22)

Includes bibliographic references. 1.Suspended sediments -- South Carolina -- Charleston. 2. Wharves -- South Carolina -Charleston. 3. Charleston Harbor (S.C.) I. Teeter, Allen M. II. United States. Army. Corps of Engineers. III. Engineer Research and Development Center (U.S.) IV. Coastal and Hydraulics Laboratory (U.S.) V. South Carolina State Ports Authority. VI. Series: ERDC/CHL TR ; 00-22. TA7 E8 no.ERDC/CHL TR-00-22 


\section{Contents}

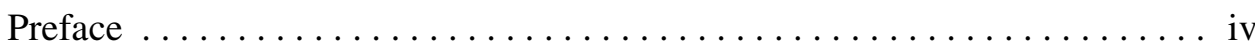

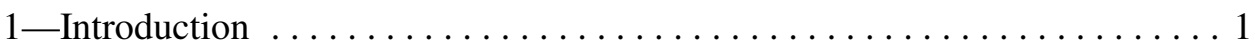

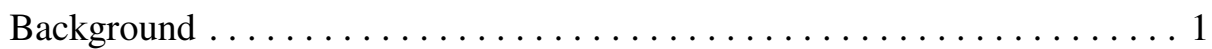

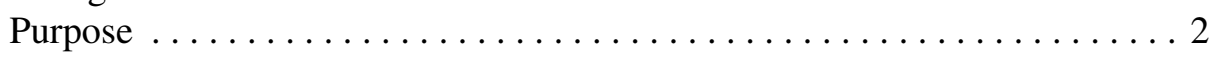

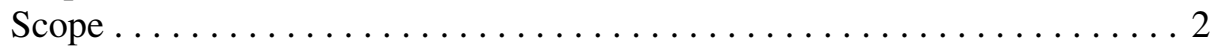

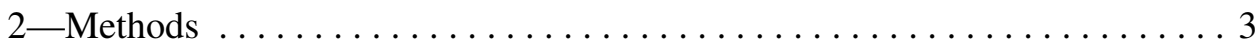

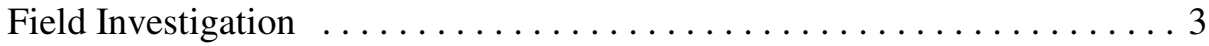

Numerical Modeling $\ldots \ldots \ldots \ldots \ldots \ldots \ldots \ldots \ldots \ldots \ldots$

$3-$ Results of Field Measurements $\ldots \ldots \ldots \ldots \ldots \ldots \ldots \ldots \ldots \ldots \ldots \ldots \ldots$

$4-$ Results of Model Tests $\ldots \ldots \ldots \ldots \ldots \ldots \ldots \ldots$

5 -Summary and Conclusions $\ldots \ldots \ldots \ldots \ldots \ldots \ldots \ldots \ldots \ldots \ldots \ldots \ldots \ldots$

Tables 1-5

Figures 1-28

SF 298 


\section{Preface}

The study described herein was conducted from October 1999 to February 2000 for the South Carolina State Ports Authority by personnel of the U.S. Army Engineer Research and Development Center (ERDC), Waterways Experiment Station (WES), Coastal and Hydraulics Laboratory (CHL). General supervision was provided by Dr. James R. Houston, former Director, CHL; Mr. Thomas Richardson, Acting Director, CHL; and Dr. Rob McAdory, Chief, Tidal Hydraulics Branch (TB), CHL.

Messrs. Allen M. Teeter, Gary L. Brown, Christopher J. Callegan, and Mses. Darla C. McVan and M. Soraya Sarruff, all of TB, conducted the model study and prepared this report for publication by CHL. Messrs. Tim Fagerburg, Terry Waller, Howard Benson, and Allen Teeter performed the field data collection. Mr. Doug Brister, TB, performed laboratory analyses on field sediment and water samples.

At the time of publication of this report, Dr. James R. Houston was Director of ERDC, and COL James S. Weller, EN, was Commander.

This report should be cited as follows:

Teeter, A. M., Brown, G. L., Callegan, C.J., McVan D. C., and Sarruff, M. S. (2000). "Sedimentation response to wharf expansion plans for the Columbus Street Terminal, Charleston, SC," ERDC/CHL TR-00-22, U.S. Army Engineer Research and Development Center, Vicksburg, MS.

The contents of this report are not to be used for advertising, publication, or promotional purposes. Citation of trade names does not constitute an official endorsement or approval for the use of such commercial products. 


\section{Introduction}

At the request of the South Carolina State Ports Authority (SCSPA), the U.S. Army Engineer Research And Development Center (ERDC), Waterways Experiment Station, Coastal and Hydraulics Laboratory (CHL), planned and carried out an investigation into shoaling adjacent to the Columbus Street Terminal wharf, Charleston, SC, and the possible effects of proposed wharf expansion plans on this shoaling.

\section{Background}

The Columbus Street Terminal is a container and break-bulk cargo handling facility on the Town Creek Lower Reach in Charleston Harbor. The location of the terminal is shown in Figure 1, along with other features and channel reaches in Charleston Harbor. Across the waterway and upstream from the terminal is Drum Island, a diked upland disposal area no longer in use. Upstream of Drum Island is the confluence of the Cooper and Wando rivers, the major subestuaries of the Charleston Harbor.

The terminal facility consists of about $1,160 \mathrm{~m}$ of wharf length with a 9-deg convex bend $503 \mathrm{~m}(1,650 \mathrm{ft})$ from its southern end. The wharf deck is $46 \mathrm{~m}$ wide and originally extended about $40 \mathrm{~m}$ over water. The Federal project depth was $10.7 \mathrm{~m}$ when the wharf was constructed in the early 1970s. The bed slope under the wharf was originally uniform at about 1:4 according to plan drawings. Mr. Larry Setzler, SCSPA, reported that shoaling has occurred under the wharf and that depths $8 \mathrm{~m}$ back from the wharf face are 2-3 $\mathrm{m}$. The authorized Federal project for the area south of the wharf bend is $13.7 \mathrm{~m}$. The area off the wharf is presently dredged by SCSPA to $13.7 \mathrm{~m}$ including overdepth and advanced maintenance allowances. Construction has begun to deepen many Federal channels to the 13.7-m-authorized depth.

The area maintained by SCSPA is the 38.1-m width between the wharf face and the Federal channel. (SCSPA actually dredges to 46-m width to insure no runback into their area.) Maintenance dredging requirements have been most severe from the wharf bend southward. Dredging cycles have been 4 to 5 months and pay volumes have averaged about $76,500 \mathrm{~m}^{3}$. Some material slumps from under the wharf during dredging, increasing volumes. Maximum actual shoal thicknesses of $2.7 \mathrm{~m}$ have accumulated in four months. 


\section{Purpose}

SCSPA is considering alternate plans which would expand the wharf toward the Federal channel as shown in Figures 2 - 4, and naturally is concerned about shoaling adjacent to any such expansion. The purpose of this study was to collect field information to identify conditions and processes contributing to the present shoaling, and to make model simulations to predict shoaling adjacent to the proposed wharf expansions.

\section{Scope}

Field information was collected by profiling currents, sampling the water column for salinity and total suspended material, and bed sampling for sediment grain size and bulk wet density. Supplemental information was collected using dual-frequency acoustic and electrical resistivity methods to detect the presence of fluid mud layers.

An existing multidimensional numerical hydrodynamic and sediment transport model was refined in the study area, verified against field information, and used to make predictions of the sedimentation response to the proposed wharf expansion plans. 


\section{Methods}

\section{Field Investigation}

A four-person field crew using CHL equipment was in the field from 12 to 15 October 1999. Currents were profiled from CHL along five transects established along and upstream from the Columbus Street Terminal wharf. Lines are shown in Figure 5 . Profiles were made using a 1,200-kHz, boat-mounted, four-beam Acoustic Doppler Current Profiler (ADCP), manufactured by RD Instruments, Inc. The beams sensed boat speed over the bottom and the relative current velocity, which were processed into a sequence of current profiles over the transects. The ADCP software calculated tidal discharges assuming logarithmic profiles over the area of the transect which could not be measured near the surface and bottom. The intensity of the backscattered ADCP signal was processed into a qualitative measure of suspended material using a previously developed method.

Water samples were collected $0.6 \mathrm{~m}$ down from the surface, $0.6 \mathrm{~m}$ up from the bottom, and at middepth along the center line of the Federal channel, about $106 \mathrm{~m}$ distance off the wharf, at the five transect lines. An ISCO ${ }^{\circledR}$ pump sampler was used with the intake fixed to a 35-kg-lead "fish" which pointed the sampler intake into the current. Samples were stored in 250-ml plastic bottles, labeled, and transported to CHL for immediate analysis. Total suspended material (TSM) was analyzed using a standard gravimetric method.

Polycarbonate filters manufactured by Nuclepore ${ }^{\circledR}$ were dried, preweighed, and used to filter known volumes of sample. The filters were dried at $105{ }^{\circ} \mathrm{C}$ for $1 \mathrm{hr}$ and reweighed. The net residual weight retained on the filter, divided by the sample volume, gave TSM concentration. Salinity was analyzed using an AGE Instruments, Inc. Autosal ${ }^{\circledR}$ instrument with an accuracy of $\pm 0.02 \mathrm{ppt}$. The instrument uses a stream of salinity standard known to an order of magnitude better than the accuracy of the instrument.

Bed sediment samples were collected using a $15-\mathrm{cm}$-square stainless-steel box core manufactured by WILDCO ${ }^{\circledR}$. The box core can collect a 23-cm-deep sediment section. The sampler allowed relatively undisturbed sediments to be brought to the boat deck and to be subsampled at the sediment surface and at approximately 15 -cm depth. Samples were stored in zip-lock plastic bags, and transported to CHL for analysis. Particle-size distribution was determined on 
sediment samples after removal of organics by three washes of Clorox alternated with sodium carbonate/bicarbonate washings, and dispersion with Calgon. A Coulter LS 100Q ${ }^{\circledR}$ was used to determine particle size from 0.4 to $1,000 \mu \mathrm{m}$. Bulk wet density (BWD) was determined using $25-\mathrm{cm}^{3}$ pycnometer. Organic content was determined as the dry weight loss on ignition (LOI) of the sample at $550{ }^{\circ} \mathrm{C}$ for $1 \mathrm{hr}$.

An Odum Echotrac ${ }^{\circledR}$ acoustic instrument with frequencies of 200 and $24 \mathrm{kHz}$ was used to measure depths and to sense for the presence of fluid mud layers. The high-frequency beam reflects off of low-density material such as fluid mud, while the low-frequency beam penetrates and reflects off of deeper and denser material. A direct-current-electrical resistivity probe built by Dr. Robert F. Corwin for CHL was used to profile soft sediments. This instrument determines sediment density with a depth resolution of about $2.5 \mathrm{~cm}$ as the probe penetrates the sediment column.

\section{Numerical Modeling}

Previous CHL studies of proposed Daniel Island wharves and access channels on the Cooper and Wando rivers developed multidimensional hydrodynamic models of the study area. The previous multidimensional models included variable spatial resolution with one-, two-, and three-dimensional areas. The most recent study was of the Wando River terminal and also developed a sedimentation model - the starting point for this study.

The numerical model applied was TABS-MDS, a modified version of the RMA-10 model originally developed by Dr. Ian King of Resource Management Associates ${ }^{1}$ and extensively modified by CHL. ${ }^{2,3}$ The numerical mesh covers the entire Charleston Harbor, the Cooper River up to the Pinopolis Dam, and large parts of the Wando and Ashley rivers. The mesh was originally based on a twodimensional depth-averaged mesh that was based on bathymetric data from the early 1980s. For this study, bathymetric data from a National Ocean Survey 1993 survey were used to update model depths in the study area and seaward to

${ }^{1}$ King, I. P. (1993). "RMA-10, a finite element model for three-dimensional density stratified flow," Department of Civil Environmental Engineering, University of California, Davis, CA.

${ }^{2}$ Berger, R. C., McAdory, R. T., Schmidt, J. H., Martin, W. D., and Hauck, L. H. (1995). "Houston-Galveston Navigation Channels, Texas, project: Report 4, Three-dimensional numerical modeling of hydrodynamics and salinity," Technical Report HL-92-7, U.S. Army Engineer Waterways Experiment Station, Vicksburg, MS.

${ }^{3}$ Teeter, A. M., Brown, G. L., Alexander, M. P., and Sarruff, M. S. (2000). "Sediment resuspension and circulation of dredged material in Laguna Madre, Texas," draft report, U.S. Army Engineer Research and Development Center, Vicksburg, MS. 
the jetties. Additional bathymetric data were collected in the study area during the CHL field data collection effort and used to update model depths.

The numerical model solves implicit equations for the conservation of mass and momentum, including nonlinear advection and friction terms, using the method of weighted residuals over a finite-element mesh. Salt and suspended sediment transport were calculated based on the instantaneous flows. Boundary conditions were supplied at the outer edge of the ocean area and at the upstream river boundaries. The boundary conditions included combinations of water level, flow discharge, salinity, and suspended sediment concentration conditions appropriate to the particular point. The hydrodynamic model, without salinity or sediments, could be spun up in about a tidal cycle. Salinity-transport calculations were initialized using a steady-state calculation for the initial salinity field. The salinity-transport portion of the model was coupled through density terms to the hydrodynamic model, and required about a week of repeating-tide spinup to reach a quasiequilibrium condition. Sediment parameters were supplied to the model as uniform initial conditions. As the simulations progressed, some sediment conditions such as bed-density profiles and water-column concentration profiles adjusted to the flow. Other conditions such as settling velocity are concentration dependent and adjust to the suspended-sediment concentration field. Because of these adjustments, the sediment model had to be spun up for many tidal cycles to reach a quasiequilibrium with respect to sediment conditions.

Horizontal model resolution was increased in the study area and resolution was increased to four elements in the vertical. After revising the model to the 1993 bathymetry, the model was used to simulate a period in June 1996 for which field data were available for a wide area of the system. Model water levels are compared to field measurements in Figure 6. The model reproduced water levels adequately in the study area. The plan geometries for the proposed wharf expansions were installed in the model by eliminating certain model elements or subdividing and retaining parts of some elements. This made it possible to make node-to-node comparison of results, and avoided mesh resolution changes which would have complicated the interpretation of plan comparisons. Model geometries for the three plans are shown in Figures 7 - 9.

The model was used to simulate the period of 12 to 15 October 1999 to verify that the model tidal discharges, salinity stratification, and suspended sediment concentrations were in reasonable agreement with field observations. For the estimation of plan effects on sedimentation, the model was used to simulate a longer, schematic spring-neap-spring tidal sequence. This synthetic tidal boundary wrapped around on itself, so that tidal hydrodynamics from a single spring-neap-spring cycle could be used to drive sediment model computations for many such cycles. In this way it was possible to operate the sediment model over a much longer simulation time than would have been possible had it been coupled directly to the hydrodynamic model. 


\section{Results of Field Measurements}

A total of 56 ADCP profiles were made over the four-day field survey. Lines 1 to 4 were bank-to-bank transects and gauged the entire tidal flow in Town Creek Upper Reach, while Line 5 extended into the Customs House Reach sufficiently to detect flow in Hog Island Reach as well. Tidal flows for these lines are shown in Figure 10. On 12 October, a ebb tidal-phase peak discharge in Town Creek Upper Reach was observed to reach $-2,385 \mathrm{~m}^{3} / \mathrm{sec}\left(-84,215 \mathrm{ft}^{3} / \mathrm{sec}\right)$ for a $1.81-\mathrm{m}$ tide range recorded at the Customs House gauge. On 13 October, the peak flood was observed to reach $2,043 \mathrm{~m}^{3} / \mathrm{sec}\left(72,165 \mathrm{ft}^{3} / \mathrm{sec}\right)$ for a $1.68 \mathrm{~m}$ tide range. On 14 October, a transition from flood the ebb tidal discharge was observed, and on 15 October a peak flood tidal discharge of $1,971 \mathrm{~m}^{3} / \mathrm{sec}$ $\left(69,616 \mathrm{ft}^{3} / \mathrm{sec}\right)$ was observed for a 1.65 tide range. The tidal record at the Customs House gauge indicated that a subtidal setup occurred 12 and 13 October, and a setdown occurred 14 and 15 October. Comparison of these Town Creek Upper Reach tidal discharges with those of Drum Island Reach measured 4 and 5 June 1996 indicate that on ebb tidal-phase about the same discharges occur in the two reaches, while the flood-phase discharge on Town Creek Upper may be 10 percent greater than Drum Island Reach, for the same tide range.

The most notable features of the tidal flow with respect to the Columbus Street Terminal can be summarized as follows:

a. Near-bottom flows were observed to be directed toward the wharf during flood- and often during ebb-tidal phases.

b. Maximum current magnitudes occurred on the Drum Island side of Town Creek Upper Channel.

c. Currents along the southern portion of the wharf were weak.

Water column measurements indicated an appreciable vertical variation in the TSM concentrations. Median TSM values were 12, 26, and $76 \mathrm{mg} / \mathrm{L}$ for the surface, middepth, and bottom samples. There was no important trend in the TSM values between the transect lines. There was a significant correlation 
between near-bottom TSM value and salinity, with higher TSMs correlated with higher salinities. This relationship is displayed in Figure 11, and indicates that the sediment source for the high concentration near-bottom TSMs was seaward of the study area and that flood tide transports them to the proximity of the wharf. ADCP backscatter intensity was first correlated with measured TSM values, and then regression coefficients were used to convert backscatter intensity to a correlated-TSM parameter. The ADCP profiles indicated that high correlated-TSM values were located on the wharf side of the channel. An example plot of flood-tidal phase correlated-TSMs for Line 5 is shown in Figure 12.

A total of 56 bed-sediment samples were collected for the Federal channel center line at 150-m intervals from wharf sta 500 to 3000 (south to north, see Table 1), and along transect lines 3 and 5 at 30, 60, 90, 120, 150, 180, 210, and $240 \mathrm{~m}(100,200,300,400,500,600,700$, and $800 \mathrm{ft}$ ) from the wharf (see Tables 2 and 3). Two samples were collected at each location, as previously described. The surface and 15-cm-depth samples are indicated by s- and b-suffixes in the station designations of the tables.

Along the Federal channel center line there was an increasing trend in bulk wet densities (BWDs) with northward distance along the wharf. At wharf sta 500 , average BWD was $1,200 \mathrm{~kg} / \mathrm{m}^{3}$, and it increased to $1,480 \mathrm{~kg} / \mathrm{m}^{3}$ at wharf sta 3000 .

Transect line 5 BWDs increased with distance from the wharf, starting at $1,160 \mathrm{~kg} / \mathrm{m}^{3}$ and gradually increasing to about $1,500 \mathrm{~kg} / \mathrm{m}^{3}$. Transect line 3 BWDs were generally in the 1,200 to $1,300 \mathrm{~kg} / \mathrm{m}^{3}$ range. There were mixes of sediment grain sizes in the study area. Vertical differences can be seen in Tables 1-3 between samples at the same locations. Sediments became generally coarser from south to north at the channel center line and with distance off the wharf.

Organic content as indicated by LOI from representation samples are given in Table 4. LOIs appear to correlate to grain size and BWD.

The dual-frequency echo sounder detected fluid mud material in the cut left by the July 1999 dredging of the areas south of the wharf bend (wharf sta 0 to 1650, Berths 1 and 2). Fluid mud is usually considered to have BWDs of less than about $1,200 \mathrm{~kg} / \mathrm{m}^{3}$ which was confirmed by BWD measurements on sediment samples from this area. Unfortunately, the electrical resistivity probe cable malfunctioned, and no useful information was obtained with this instrument. Figures 13 - 16 show two dual-frequency echo sounder transects near wharf sta 1000 , a longitudinal transect $10 \mathrm{~m}$ off the wharf, and a transect at wharf sta 2500 . The dredge cut and fluid mud layer were roughly $550 \mathrm{~m}$ $(1,800 \mathrm{ft})$ long (Figure 15), $38 \mathrm{~m}$ (125 ft) wide, and $2.1 \mathrm{~m}(7 \mathrm{ft})$ deep (Figures 13 and 14). Fluid mud material was observed to be disturbed and resuspended by vessels maneuvering to and from the terminal. However, outside this area near the wharf, we did not detect an appreciable accumulation of fluid mud, nor did we observe any in the box-core sediment samples. 


\section{Results of Model Tests}

The hydrodynamic model produced currents and salinity stratifications which were in reasonable agreement with 12 - 15 October 1999 field observations. An example model current transect along line 5, shown in Figure 17, is comparable to measured ADCP currents shown Figure 18. In both cases, currents are lowest along the wharf and do not become appreciable until about $300 \mathrm{~m}$ off the wharf.

The synthetic-tide hydrodynamic simulation generated a 10-tidal-cycle spring-neap-spring sequence that was used to drive the sediment model for plan tests. The spring and neap tidal ranges were 2 and $1.5 \mathrm{~m}$, respectively. The model maximum flood and ebb tidal currents for the surface and near-bottom are shown plan view in Figures 19 - 22. The flood tidal-phase bottom current can be seen converging toward the wharf in Figure 21. Model TSM concentration contours for transect Line 5 are shown in Figures 23 and 24 for maximum ebb and flood tidal flows.

The base and three plans were simulated for 50 tidal cycles, or five springneap-spring sequences, with the sediment model. Plan view sedimentation results are shown for the base and three plans in Figures 25 - 28. The SCSPAmaintained area along the wharf and out $46 \mathrm{~m}$ was divided into four sections, each $250 \mathrm{~m}$ long, from south to north. Shoaling over these sections was calculated from the model test results and normalized by the base value. Shoaling index results are summarized in Table 5.

The base model shoaling was 4,000; 3,400; 2,500; and 2,800 $\mathrm{m}^{3} /$ year for sections 1-4 along the wharf. 


\section{Summary and Conclusions}

Suspended sediments were found to be transported at highest concentration near the bottom, especially on flood tidal-phases, and known to deposit along the Columbus Street Terminal wharf. The southern half of the wharf area has especially low current speeds and requires the most frequent maintenance dredging. Sediments near the wharf are fine, cohesive muds. A layer of fluid mud about $2 \mathrm{~m}$ thick was detected in a dredge cut made along the southern half of the wharf 3 months prior to our field survey. Sediment grain size and bulk wet density generally increased with distance off the wharf and upstream. Nearbottom flood tidal-phase flows were found to converge toward the wharf and carry suspended sediment into the area adjacent to the wharf.

Three proposed wharf expansion plans were tested in a numerical finiteelement hydrodynamic and sediment transport model. The model was threedimensional in the study area with four elements in the vertical. Model tests indicated that the Plan 3 extension will reduce dredging requirements somewhat (about 13 percent relative to present conditions). The other two extension plans will not appreciably change maintenance dredging requirements. While we have confidence in the sediment model results, we are unable to define the possible error in our shoaling sediments due to lack of detailed verification. 


\begin{tabular}{|l|c|c|c|c|c|c||}
\hline \hline $\begin{array}{l}\text { Table 1 } \\
\text { Sediment Size and BWD for Center Line Samples }\end{array}$ \\
\hline \hline \multicolumn{1}{|c|}{ Station } & $\begin{array}{c}\text { Mean } \\
\boldsymbol{\mu m}\end{array}$ & $\begin{array}{c}\text { Median } \\
\boldsymbol{\mu m}\end{array}$ & Mode, $\boldsymbol{\mu m}$ & $\begin{array}{c}\text { Standard } \\
\text { Deviation }\end{array}$ & $\mathbf{D}_{\mathbf{9 0}}, \boldsymbol{\mu m}$ & $\begin{array}{c}\text { BWD } \\
\mathbf{k g} / \mathbf{m}^{3}\end{array}$ \\
\hline \hline CL-500s & 15.3 & 16.8 & 7.1 & 5.7 & 165.2 & 1197 \\
\hline CL-500b & 9.7 & 9.0 & 7.1 & 4.2 & 73.0 & 1206 \\
\hline CL-1000s & 18.1 & 18.4 & 105.9 & 5.5 & 150.6 & 1223 \\
\hline CL-1000b & 14.6 & 13.1 & 7.1 & 5.3 & 135.0 & 1207 \\
\hline CL-1500s & 24.0 & 30.2 & 116.3 & 5.8 & 173.5 & 1274 \\
\hline CL-1500b & 10.6 & 9.9 & 7.1 & 4.4 & 87.7 & 1194 \\
\hline CL-2500s & 25.3 & 32.7 & 140.1 & 6.0 & 192.7 & 1279 \\
\hline CL-2500b & 25.4 & 29.5 & 127.6 & 5.8 & 189.8 & 1293 \\
\hline CL-3000 & 269.2 & 434.8 & 905.1 & 4.7 & 839.4 & 1479 \\
\hline \hline
\end{tabular}

\begin{tabular}{||c|c|c|c|c|c|c||}
\hline \hline \multicolumn{7}{|l|}{$\begin{array}{l}\text { Table 2 } \\
\text { Sediment Size and BWD for Line 3 Samples }\end{array}$} \\
\hline \hline Station & Mean, $\mu \mathrm{m}$ & $\begin{array}{c}\text { Median } \\
\boldsymbol{\mu m}\end{array}$ & $\begin{array}{c}\text { Mode } \\
\boldsymbol{\mu m}\end{array}$ & $\begin{array}{c}\text { Standard } \\
\text { Deviation }\end{array}$ & $\mathbf{D}_{90}, \boldsymbol{\mu m}$ & $\begin{array}{c}\text { BWD } \\
\mathbf{k g} / \mathbf{m}^{3}\end{array}$ \\
\hline \hline L3-100s & 15.0 & 12.5 & 6.5 & 5.9 & 150.5 & 1203 \\
\hline L3-100b & 25.2 & 21.9 & 824.5 & 7.1 & 517.0 & 1234 \\
\hline L3-200s & 23.1 & 25.6 & 127.6 & 5.9 & 190.2 & 1238 \\
\hline L3-200b & 10.7 & 9.7 & 7.8 & 4.1 & 80.0 & 1192 \\
\hline L3-300s & 22.1 & 21.6 & 153.8 & 6.1 & 198.6 & 1280 \\
\hline L3-300b & 11.1 & 9.9 & 7.8 & 4.4 & 86.9 & 1169 \\
\hline L3-400s & 39.7 & 84.6 & 153.8 & 5.7 & 211.8 & 1369 \\
\hline L3-400b & 17.0 & 14.2 & 7.8 & 5.1 & 154.3 & 1253 \\
\hline L3-500s & 21.1 & 20.9 & 127.6 & 5.7 & 181.9 & 1299 \\
\hline L3-500b & 20.3 & 18.0 & 140.1 & 5.2 & 169.7 & 1275 \\
\hline L3-600s & 20.2 & 17.6 & 7.8 & 6.1 & 188.9 & 1256 \\
\hline L3-600b & 37.7 & 54.8 & 203.8 & 6.5 & 308.7 & 1370 \\
\hline L3-700s & 47.3 & 98.7 & 245.2 & 7.3 & 384.9 & 1454 \\
\hline L3-700b & 21.3 & 18.5 & 7.8 & 5.8 & 233.8 & 1364 \\
\hline L3-800s & 20.8 & 14.6 & 245.2 & 6.6 & 278.9 & 1420 \\
\hline L3-800b & 14.0 & 11.7 & 7.7 & 4.9 & 140.0 & 1224 \\
\hline \hline
\end{tabular}




\begin{tabular}{|c|c|c|c|c|c|c|}
\hline \multicolumn{7}{|c|}{$\begin{array}{l}\text { Table } 3 \\
\text { Sediment Size and BWD for Line } 5 \text { Samples }\end{array}$} \\
\hline Station & Mean, $\mu \mathrm{m}$ & $\begin{array}{c}\text { Median, } \\
\mu \mathrm{m}\end{array}$ & Mode, $\mu \mathrm{m}$ & $\begin{array}{l}\text { Standard } \\
\text { Deviation }\end{array}$ & $\mathrm{D}_{90}, \mu \mathrm{m}$ & $\begin{array}{l}\text { BWD } \\
\mathrm{kg} / \mathrm{m}^{3}\end{array}$ \\
\hline L5-100s & 9.7 & 8.9 & 7.1 & 4.1 & 67.3 & 1153 \\
\hline L5-100b & 10.7 & 10.2 & 7.8 & 4.2 & 75.9 & 1171 \\
\hline L5-200s & 10.9 & 10.0 & 7.1 & 4.3 & 83.8 & 1189 \\
\hline L5-200b & 12.4 & 11.6 & 7.1 & 4.6 & 102.8 & 1221 \\
\hline L5-300s & 11.1 & 10.8 & 8.5 & 5.0 & 106.7 & 1226 \\
\hline L5-300b & 13.9 & 12.6 & 7.8 & 5.8 & 173.1 & 1205 \\
\hline L5-400s & 17.0 & 16.7 & 140.1 & 5.8 & 169.4 & 1220 \\
\hline L5-400b & 14.4 & 12.8 & 7.1 & 5.3 & 146.1 & 1258 \\
\hline L5-500s & 17.8 & 17.7 & 140.1 & 6.1 & 179.6 & 1320 \\
\hline L5-500b & 10.3 & 10.0 & 7.8 & 4.5 & 86.8 & 1183 \\
\hline L5-600s & 47.3 & 92.5 & 153.8 & 6.7 & 398.3 & 1535 \\
\hline L5-600b & 16.7 & 15.4 & 8.5 & 5.8 & 182.1 & 1445 \\
\hline L5-700s & 21.3 & 21.9 & 153.8 & 6.2 & 208.0 & 1222 \\
\hline L5-700b & 30.7 & 42.0 & 168.8 & 7.1 & 273.7 & 1457 \\
\hline L5-800s & 25.9 & 29.4 & 153.8 & 127.8 & 222.4 & 1390 \\
\hline L5-800b & 79.8 & 150.6 & 168.8 & 6.3 & 547.6 & 1671 \\
\hline
\end{tabular}




\begin{tabular}{|r|r|}
\hline \multicolumn{2}{|l|}{$\begin{array}{l}\text { Table } 4 \\
\text { Loss on Ignition for Select } \\
\text { Samples }\end{array}$} \\
\hline \hline \multicolumn{1}{||r|}{ Station } & LOI, w/w percent \\
\hline \hline CL-500s & 11.9 \\
\hline CL-500b & 12.4 \\
\hline CL-1500s & 10.4 \\
\hline CL-1500b & 11.9 \\
\hline CL-3000s & 0.9 \\
\hline CL-3500b & 4.6 \\
\hline L3-100s & 12.3 \\
\hline L3-100b & 12.2 \\
\hline L3-500s & 8.9 \\
\hline L3-500b & 9.9 \\
\hline L5-100s & 12.0 \\
\hline L5-100b & 11.8 \\
\hline L5-500s & 6.9 \\
\hline L5-500b & 9.6 \\
\hline & \\
\hline &
\end{tabular}

\section{Table 5}

Model Shoaling Indices for Base and Plans

\begin{tabular}{||l|l|l|l|l||}
\hline \hline $\begin{array}{l}\text { Section (South to } \\
\text { North) }\end{array}$ & Base & Plan 1 & Plan 2 & Plan 3 \\
\hline \hline 1 & 1.0 & 1.006 & 0.903 & 0.815 \\
\hline 2 & 1.0 & 1.081 & 0.905 & 0.764 \\
\hline 3 & 1.0 & 0.893 & 1.081 & 0.888 \\
\hline 4 & 1.0 & 1.076 & 1.014 & 1.061 \\
\hline Total & 1.0 & 1.019 & 0.964 & 0.871 \\
\hline \hline
\end{tabular}

Note: Results are considered accurate to one decimal place. Extra digits shown for comparison only. 


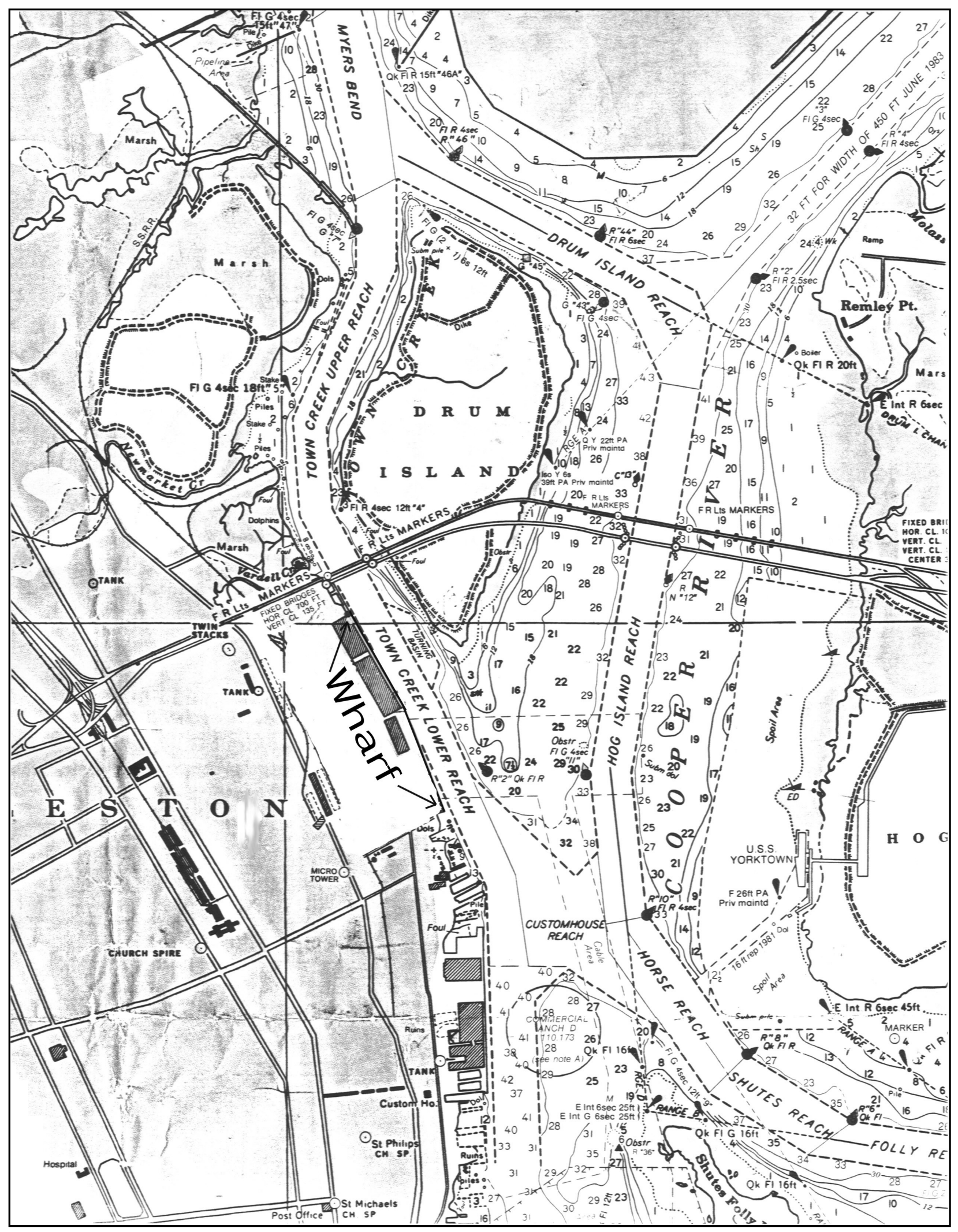

Figure 1. Channel layout in the vicinity of the Columbus Street Terminal wharf (NOS Chart 11524, $35^{\text {th }}$ edition, 10/1984) 


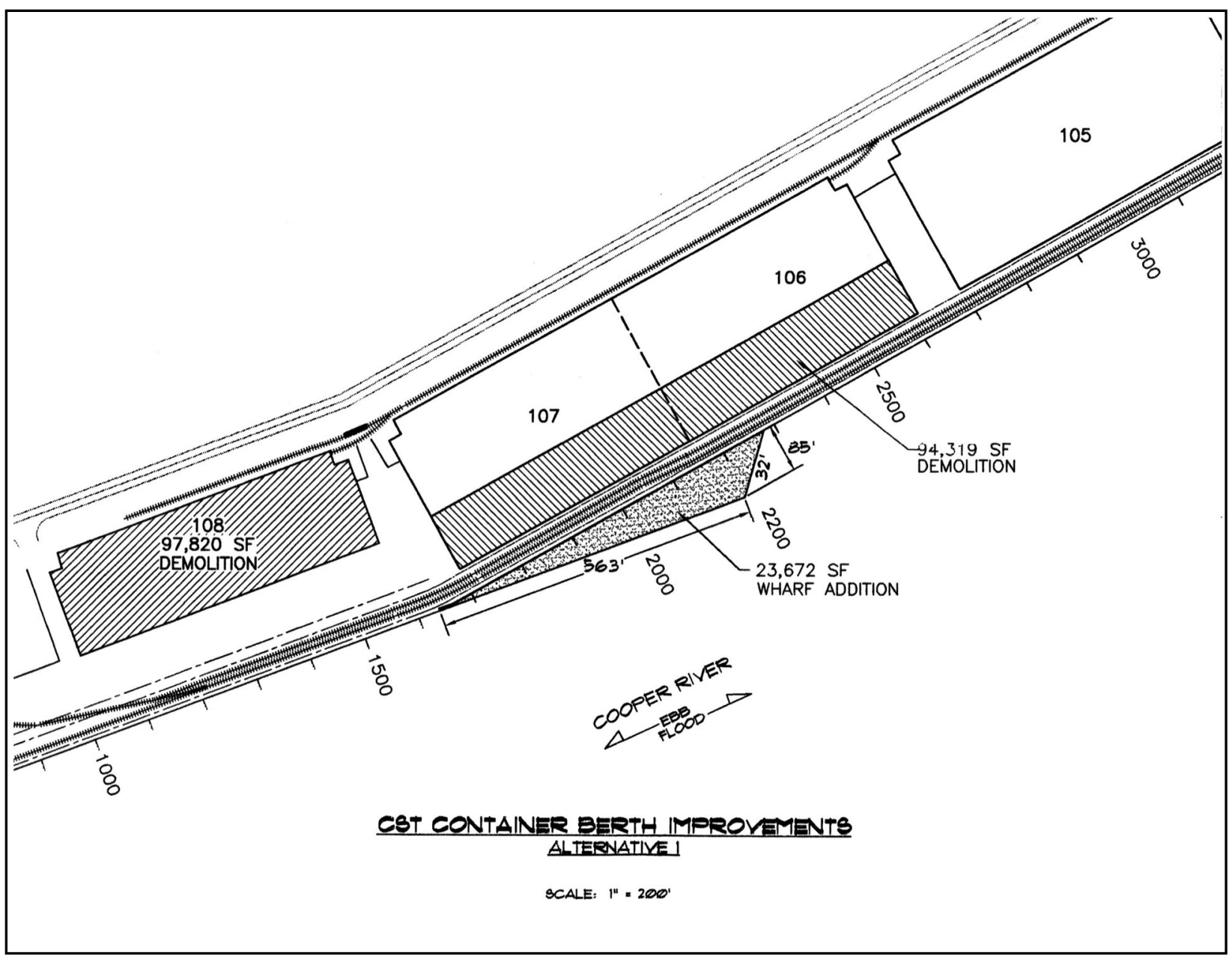

Figure 2. Plan 1 wharf expansion and stations along the wharf (Scale is in feet. To convert feet to meters, multiply by 0.3048 ) 


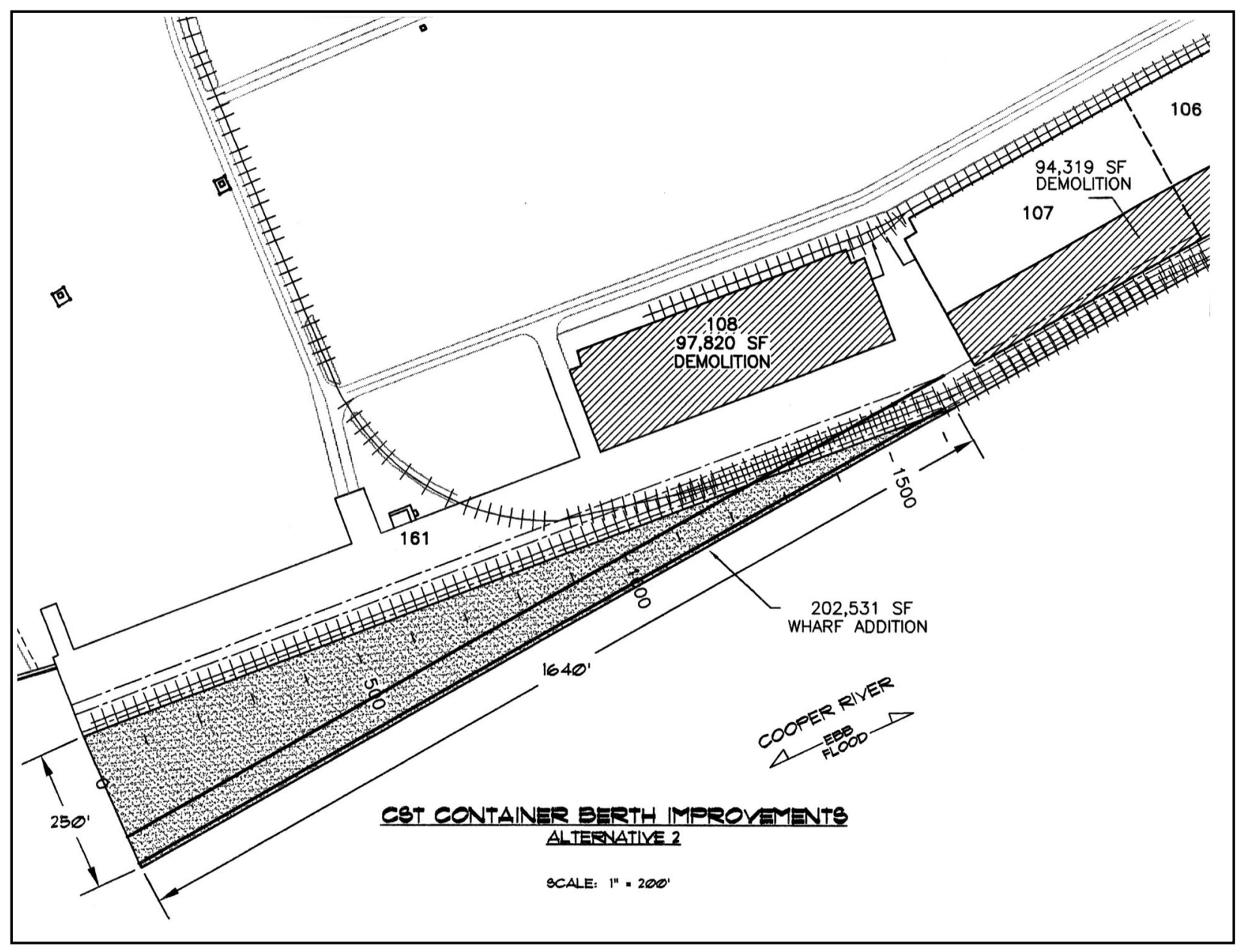

Figure 3. Plan 2 wharf expansion (Scale is in feet. To convert feet to meters, multiply by 0.3048 ) 


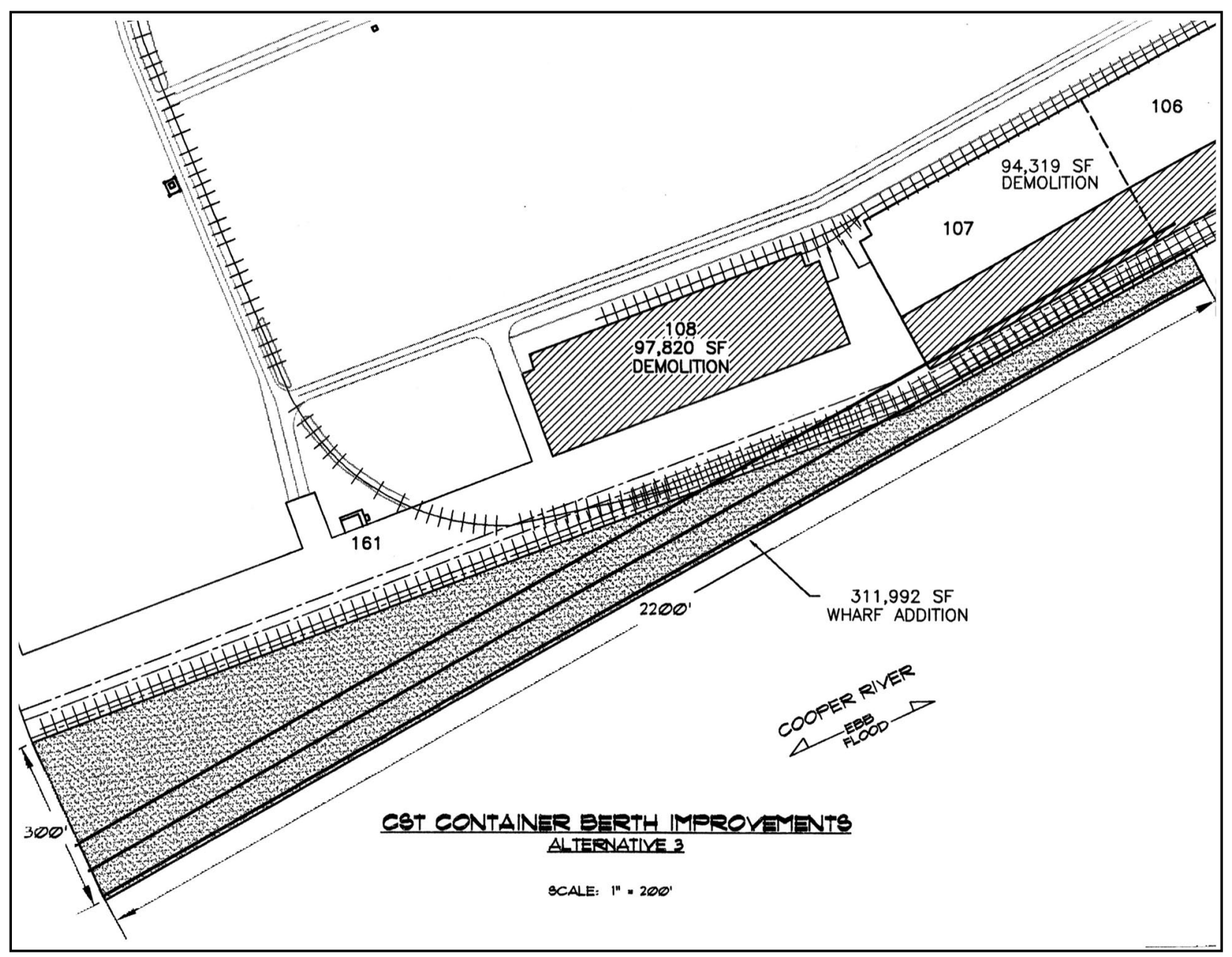

Figure 4. Plan 3 wharf expansion (Scale is in feet. To convert feet to meters, multiply by 0.3048 ) 


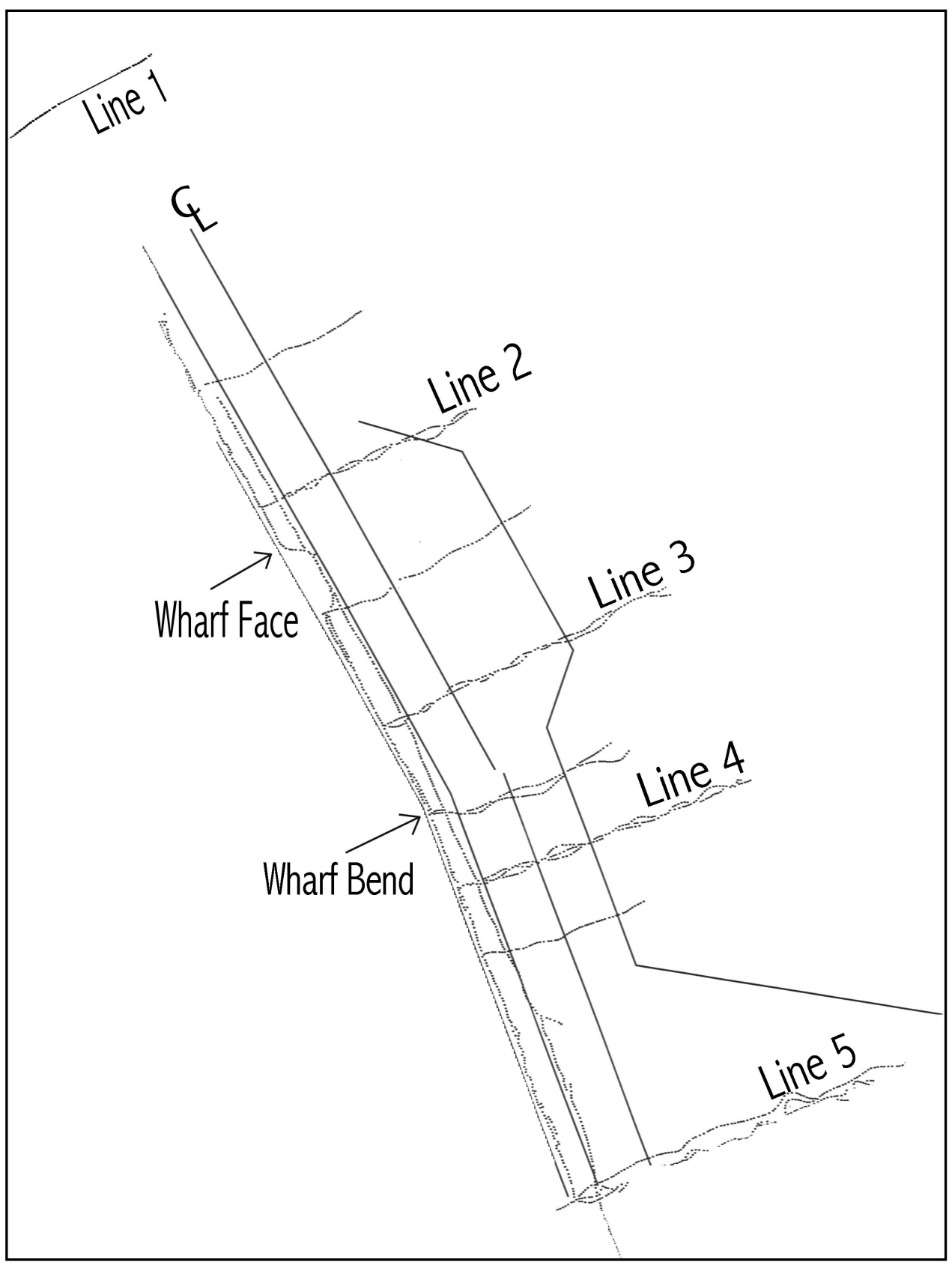

Figure 5. Position tracks of bathymetric survey lines and line designation 


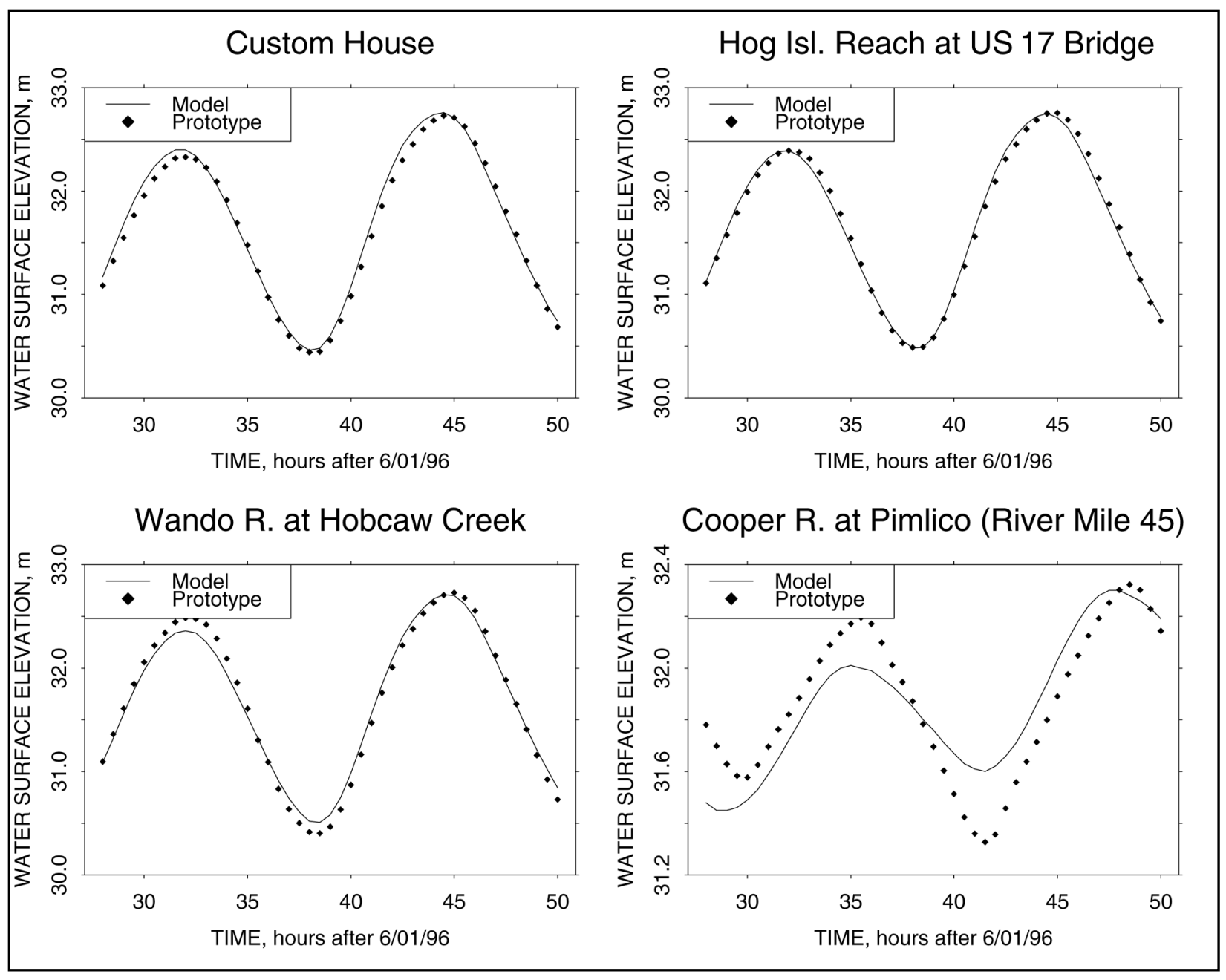

Figure 6. Model to prototype water level comparisons after model resolution and bathymetry update 


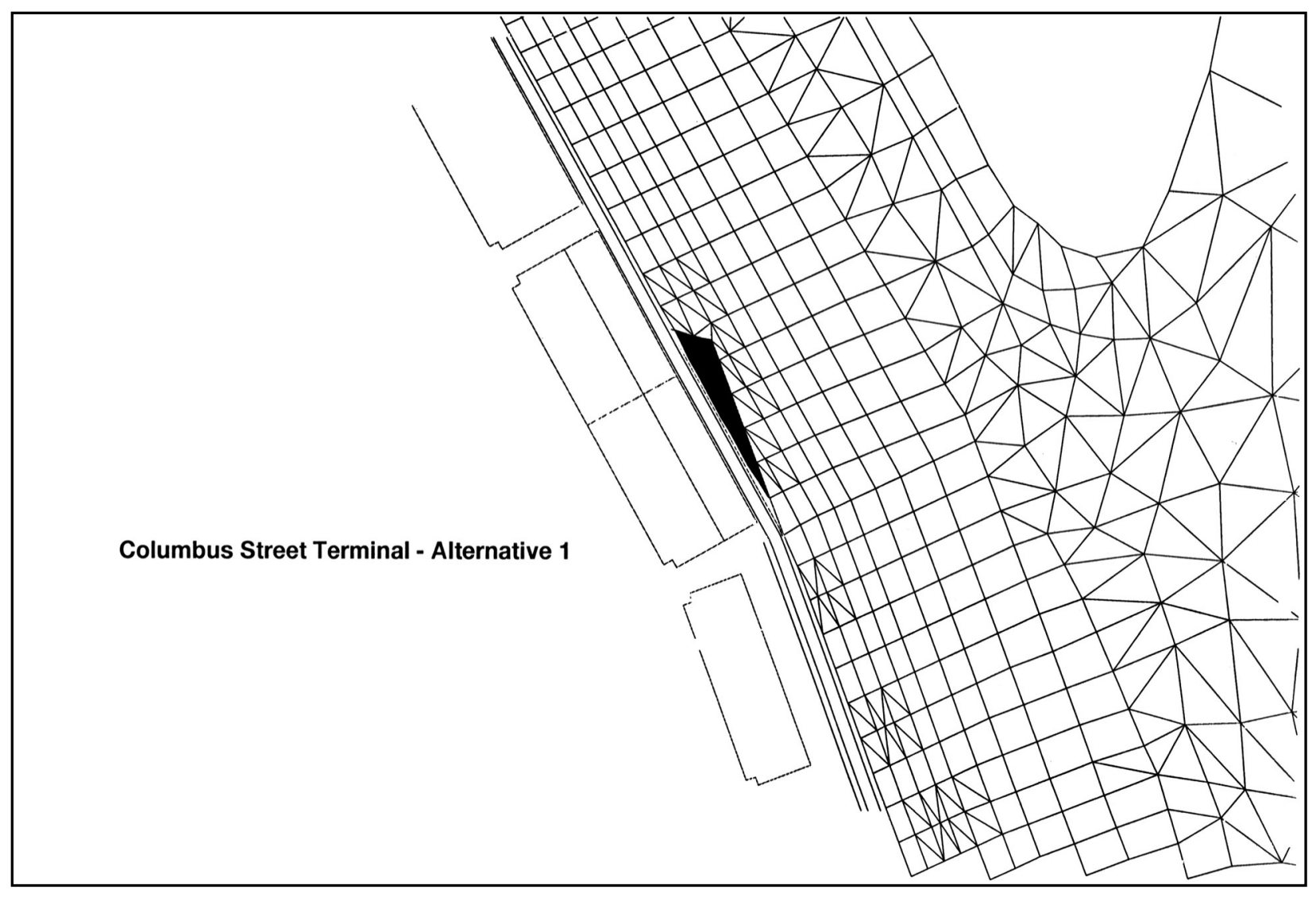

Figure 7. Plan 1 installed in the model mesh 


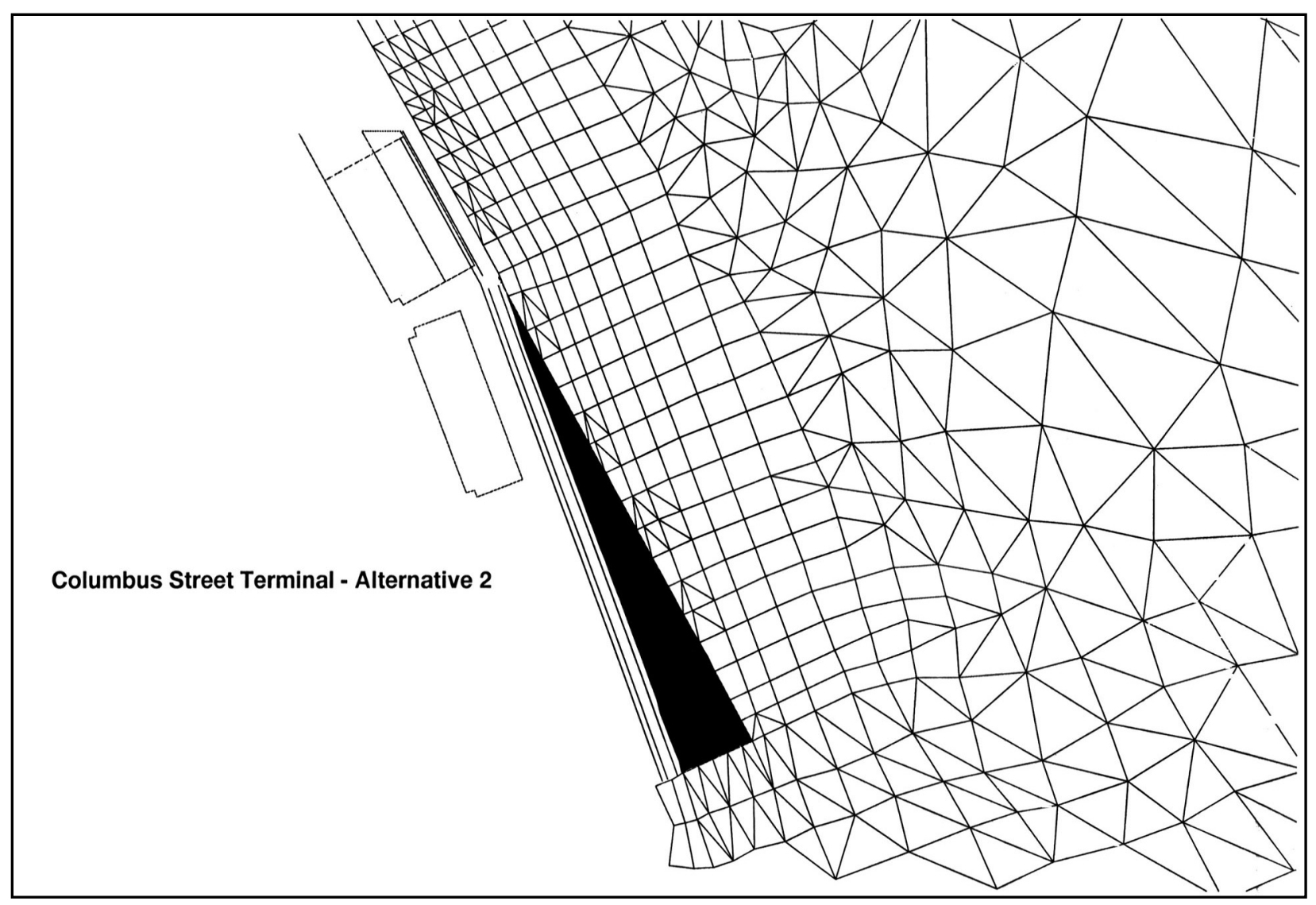

Figure 8. Plan 2 installed in the model mesh 


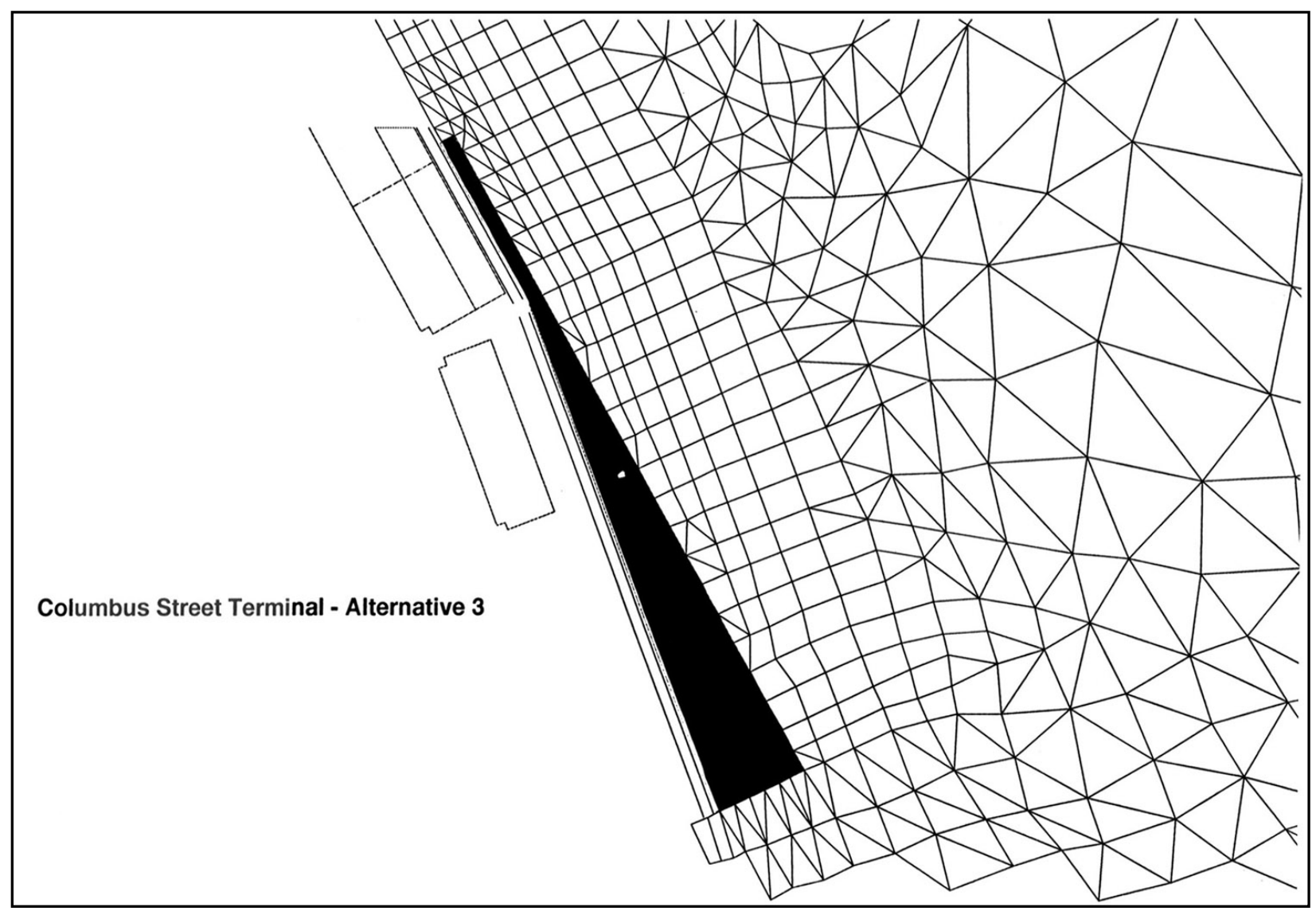

Figure 9. Plan 3 installed in the model mesh 


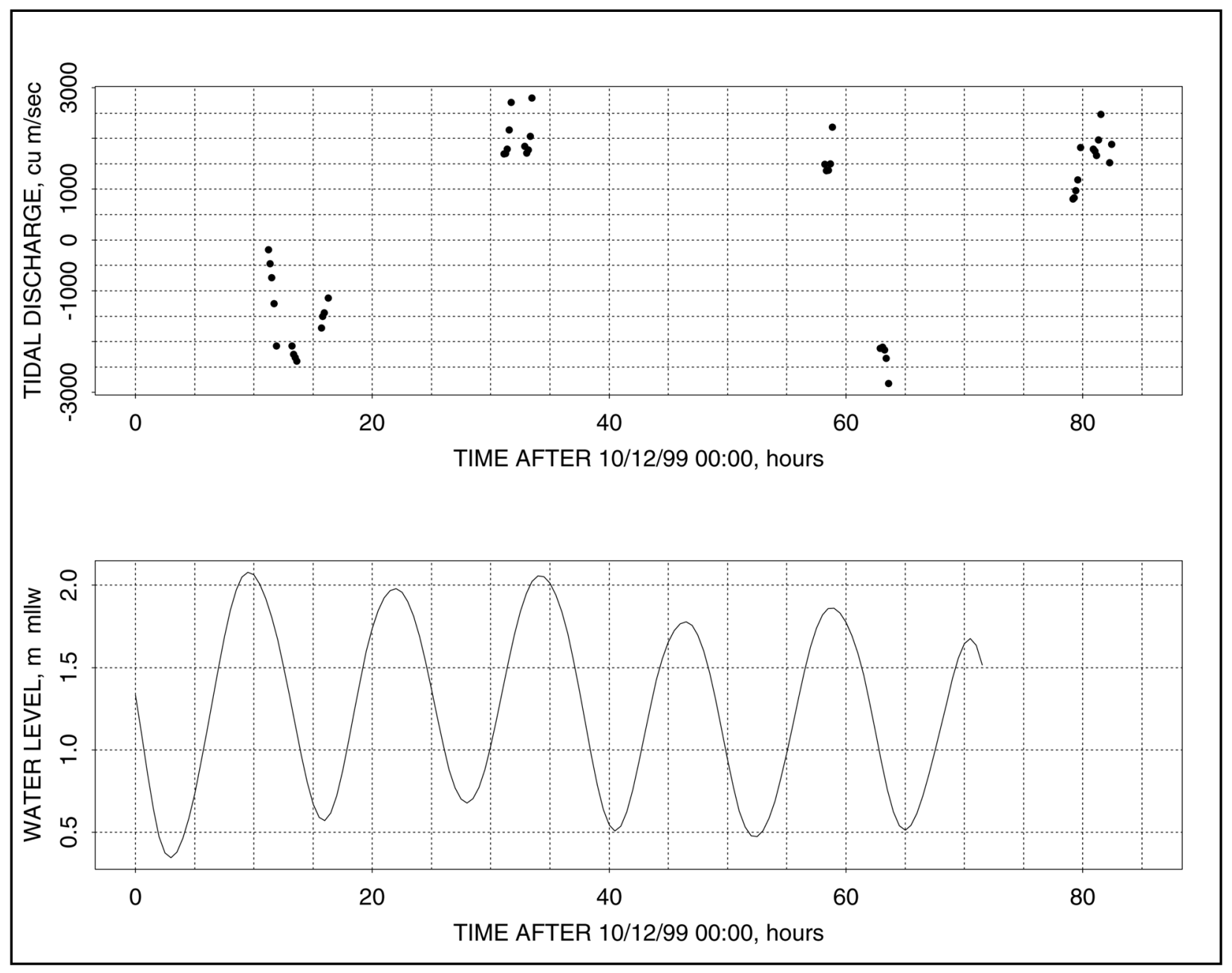

Figure 10. Tidal discharges for lines 1-4 and tidal elevations at Customs House 


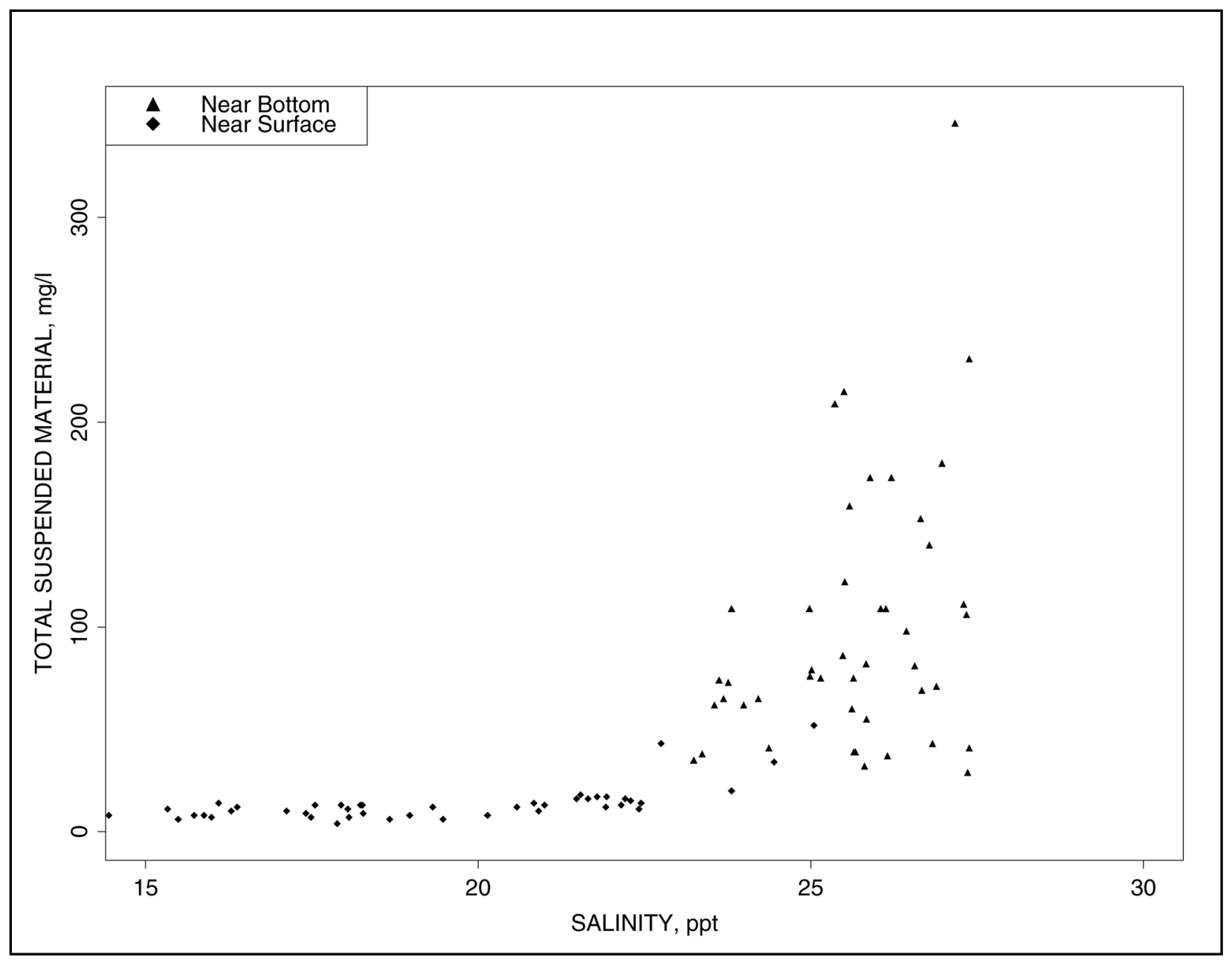

Figure 11. Scatter plot of salinity versus TSM concentrations for surface and bottom samples 


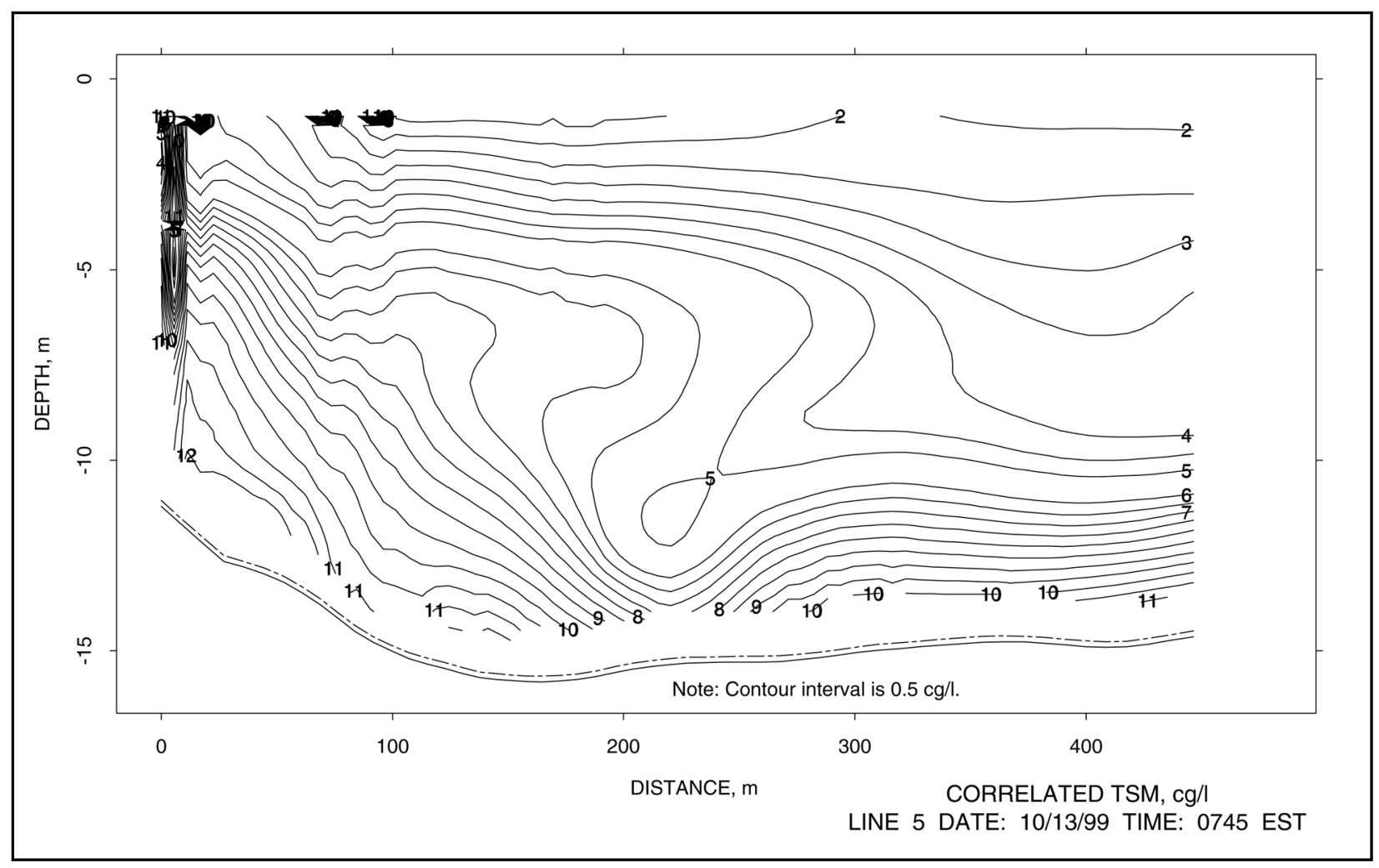

Figure 12. Example transect contour plot of correlated-TSM from line 5 (left edge is the wharf) 


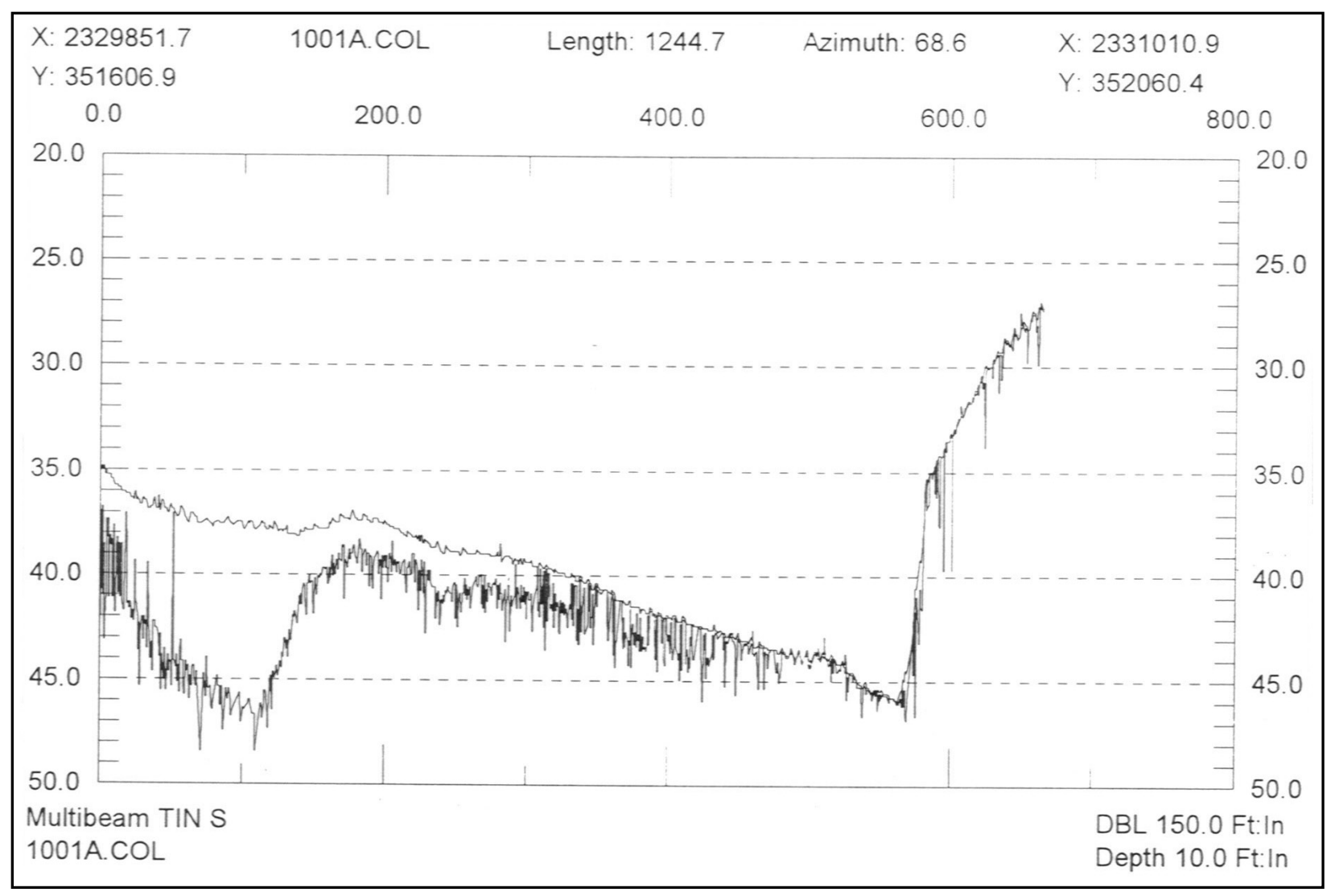

Figure 13. Dual-frequency transect near wharf sta 1000 showing the top of the fluid mud layer and the bottom of the dredge cut (left edge is the wharf) (Depth and distance is in feet. To convert feet to meters, multiply by 0.3048 ) 


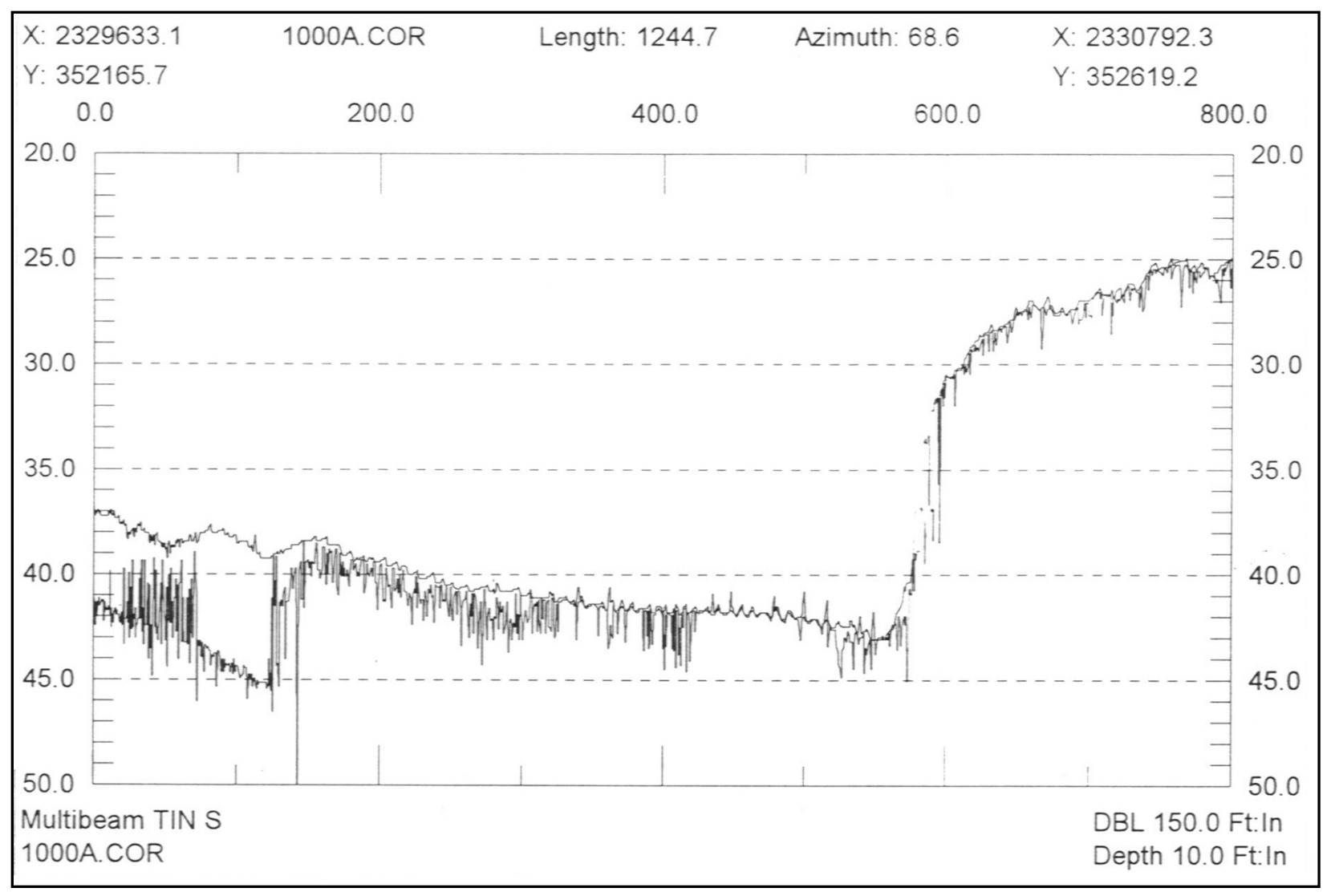

Figure 14. Dual-frequency transect near wharf sta 1000 showing the top of the fluid mud layer and the bottom of the dredge cut (left edge is the wharf) (Depth and distance is in feet. To convert feet to meters, multiply by 0.3048 ) 


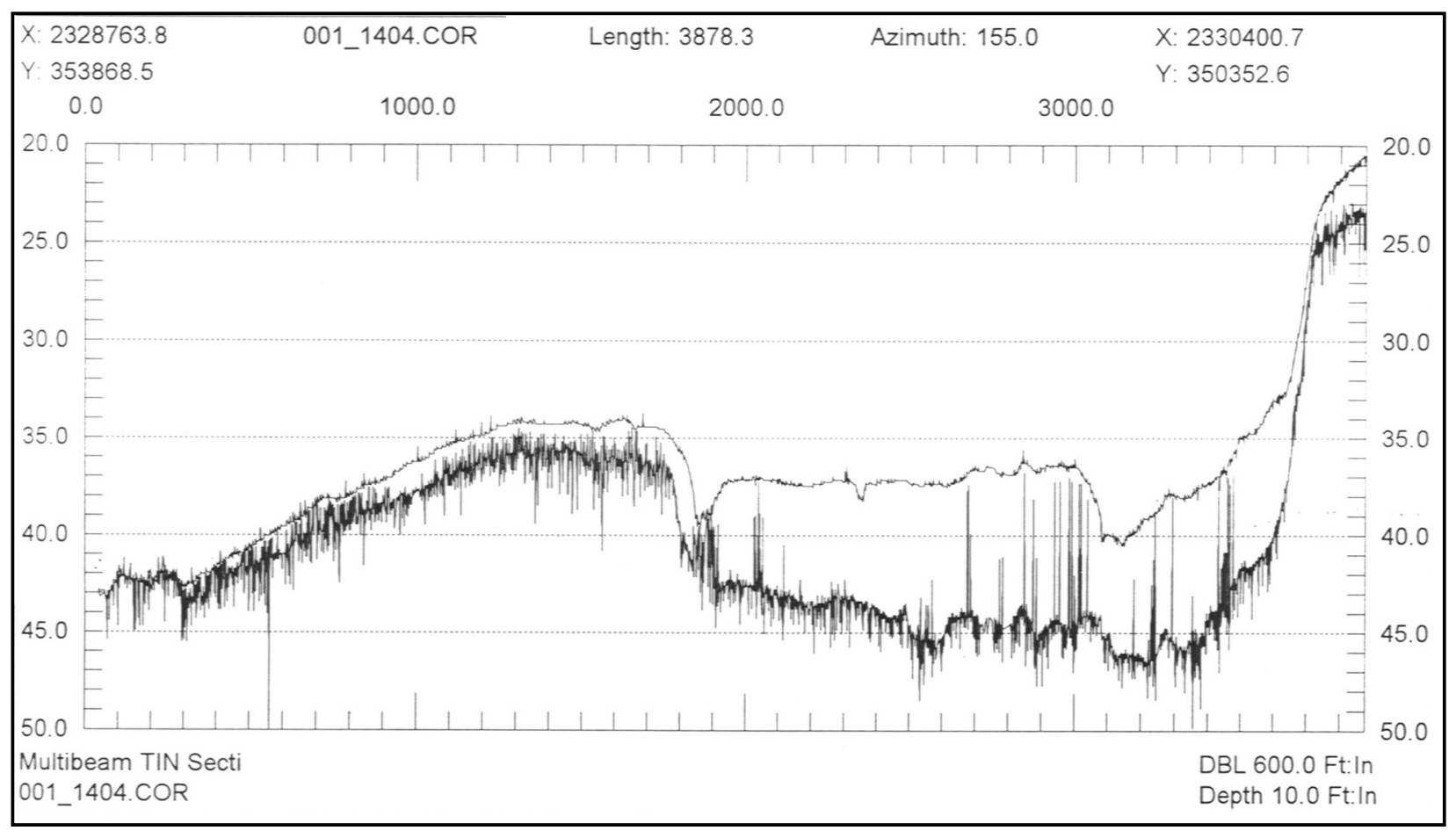

Figure 15. Dual-frequency transect parallel and $10 \mathrm{~m}$ off the wharf moving from north to south (Depth and distance is in feet. To convert feet to meters, multiply by 0.3048 ) 


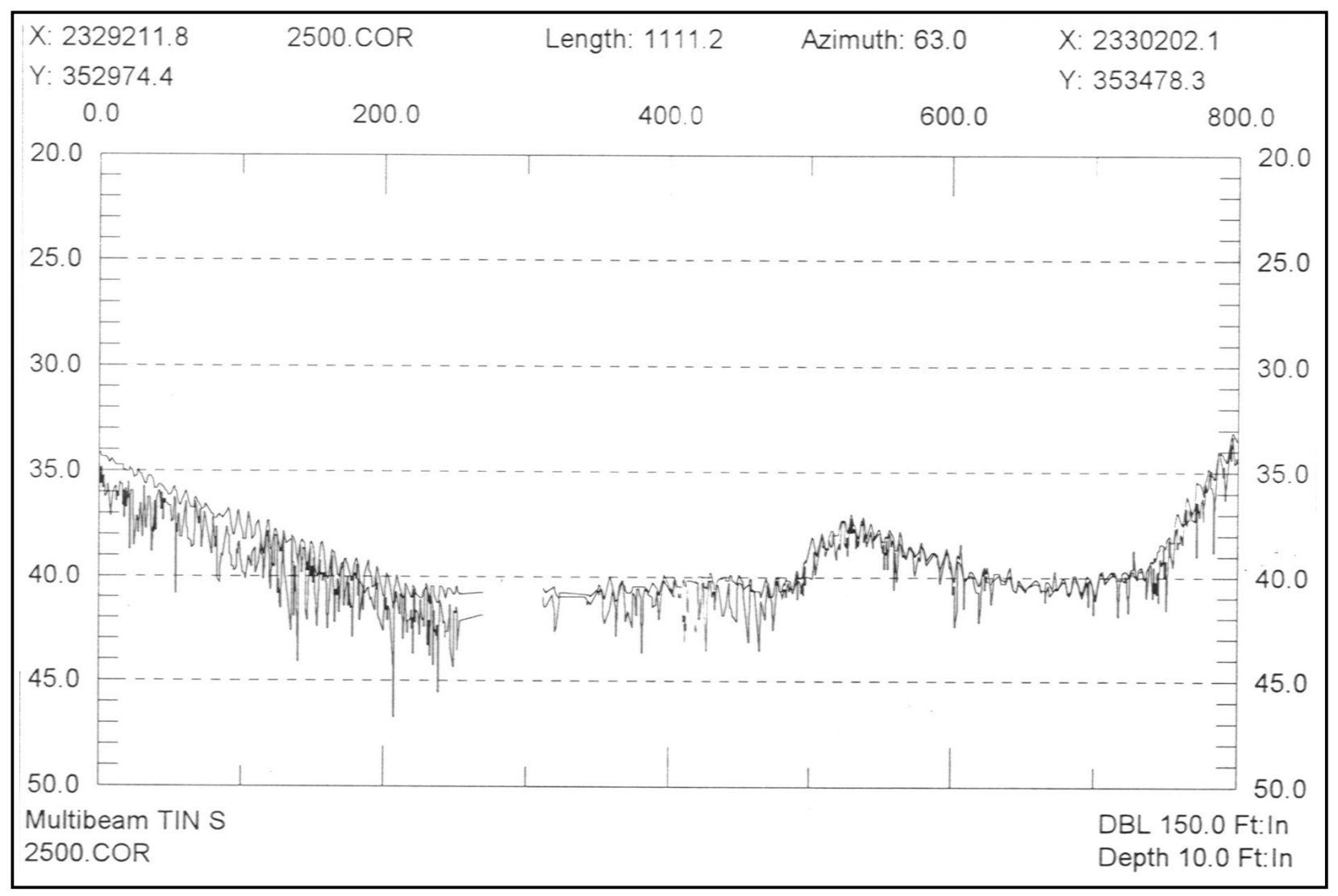

Figure 16. Dual-frequency transect near wharf sta 2500 (left edge is the wharf) (Depth and distance is in feet. To convert feet to meters, multiply by 0.3048 ) 


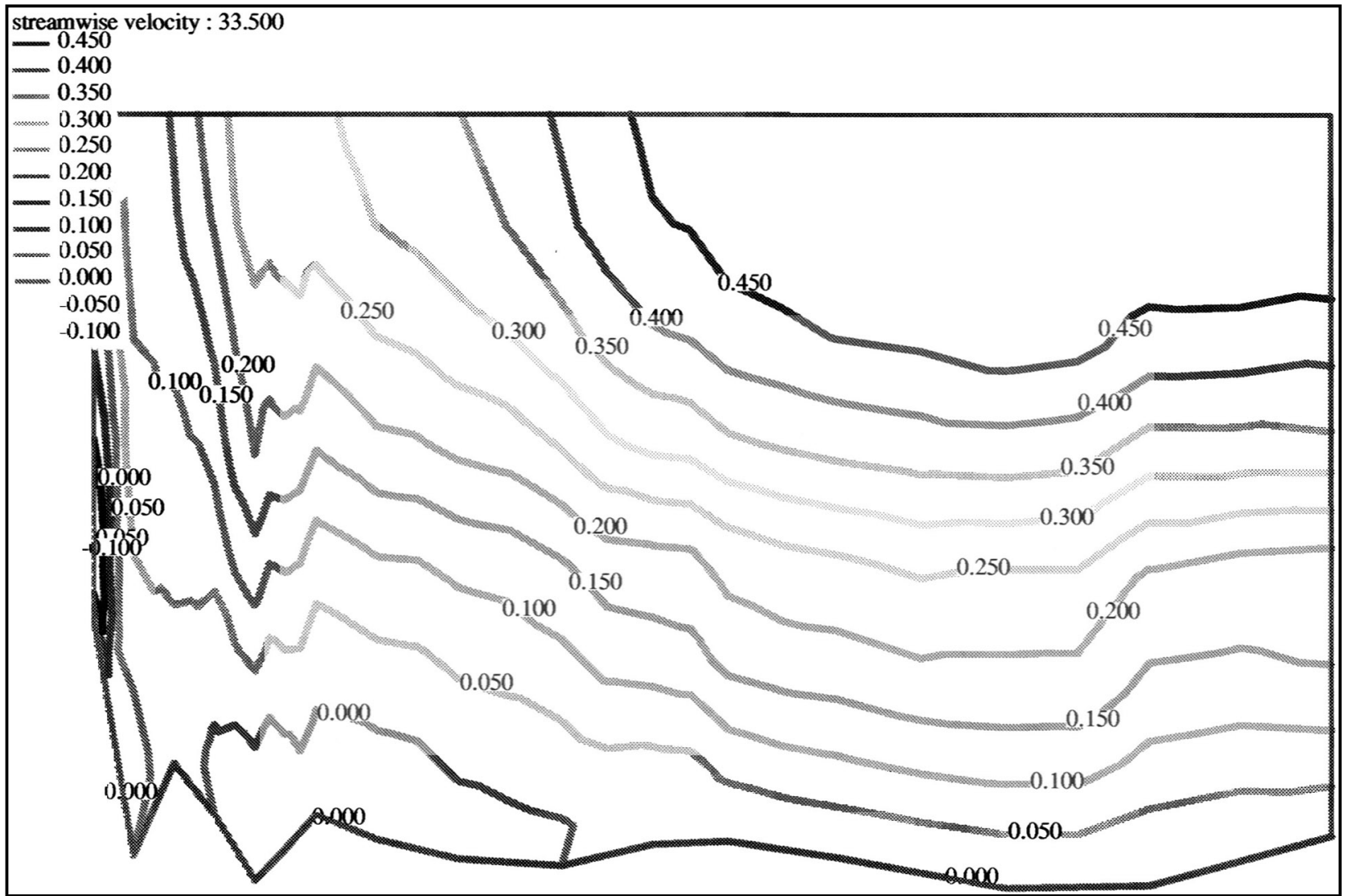

Figure 17. Vertical transect of normal current components along line 5 from the model hour 33.5 (current in $\mathrm{m} / \mathrm{sec}$ ) 


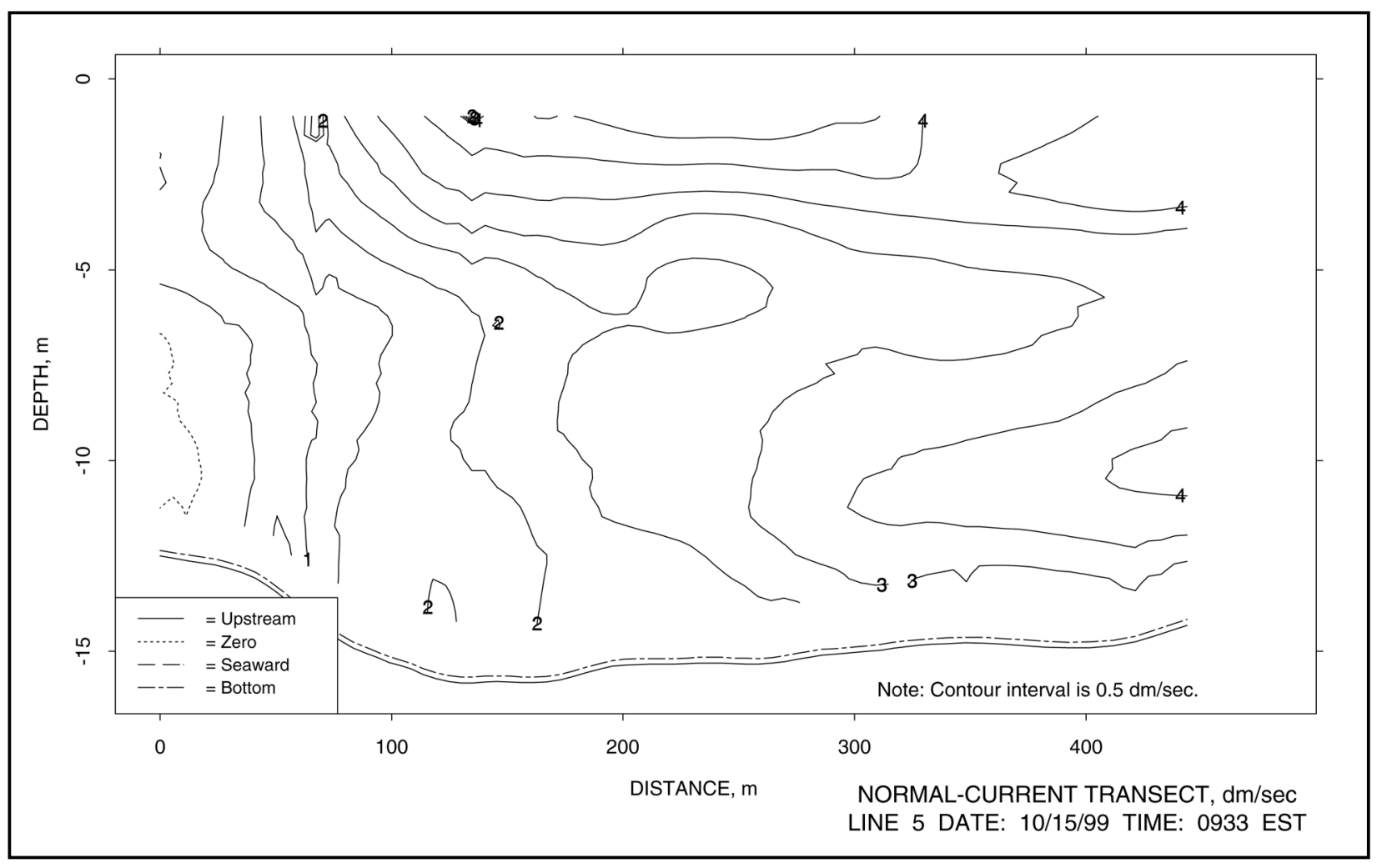

Figure 18. ADCP results for line 5 corresponding in time to Figure 15 (current in $\mathrm{dm} / \mathrm{sec}$ ) 


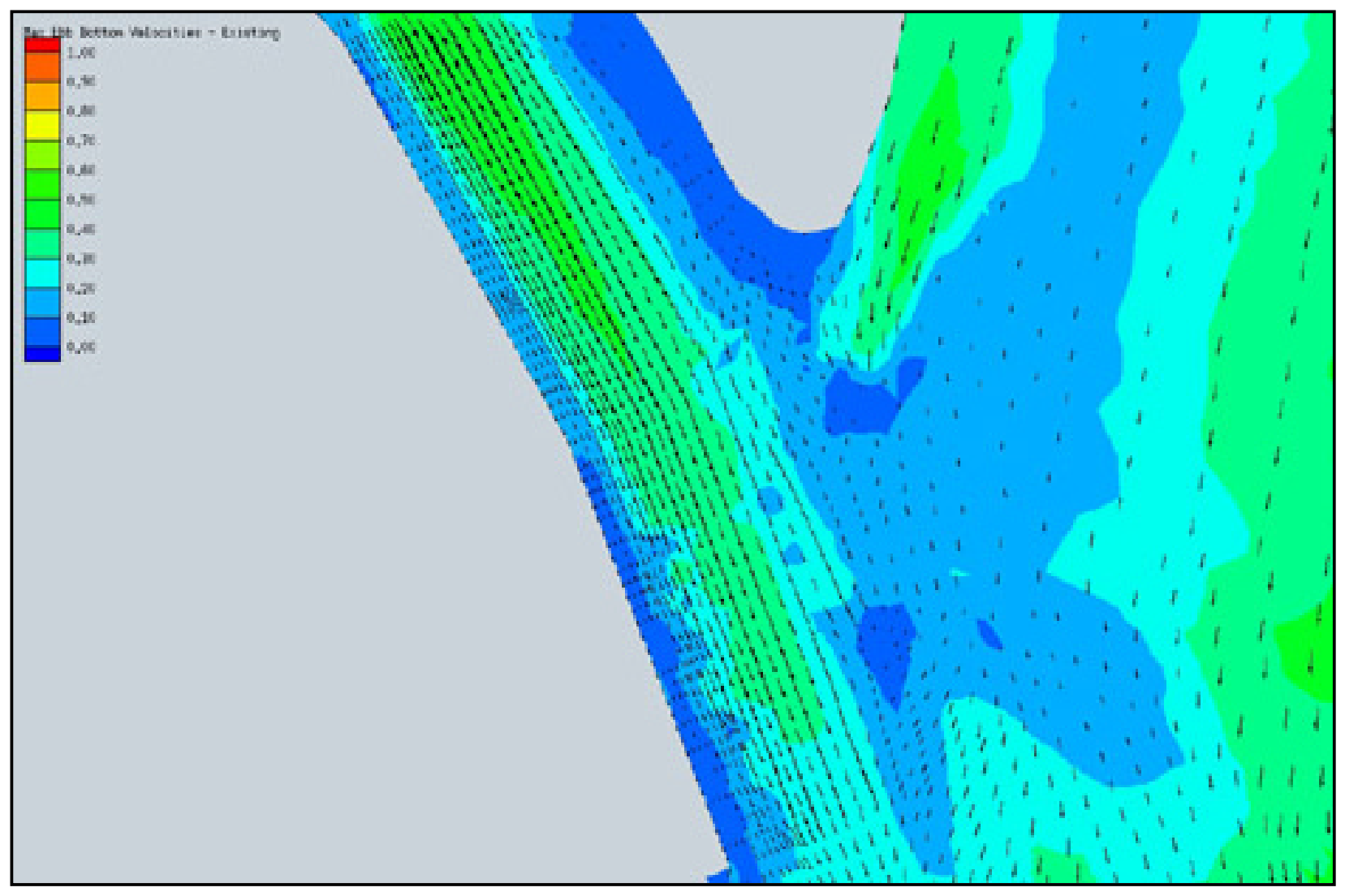

Figure 19. Near-bottom maximum ebb current vectors and speed contours in $\mathrm{m} / \mathrm{sec}$ for the existing condition 


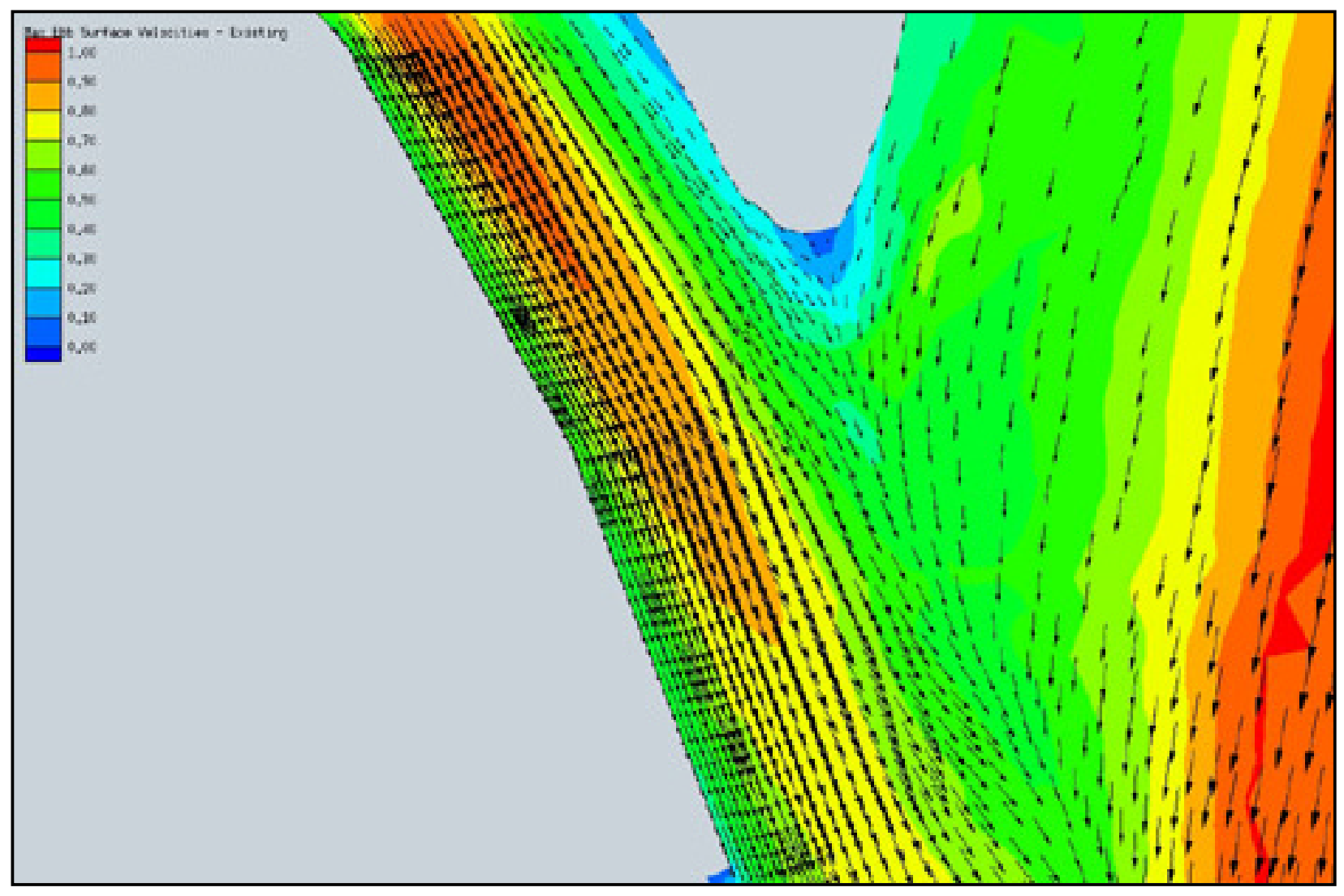

Figure 20. Surface maximum ebb current vectors and speed contours in $\mathrm{m} / \mathrm{sec}$ for the existing condition 


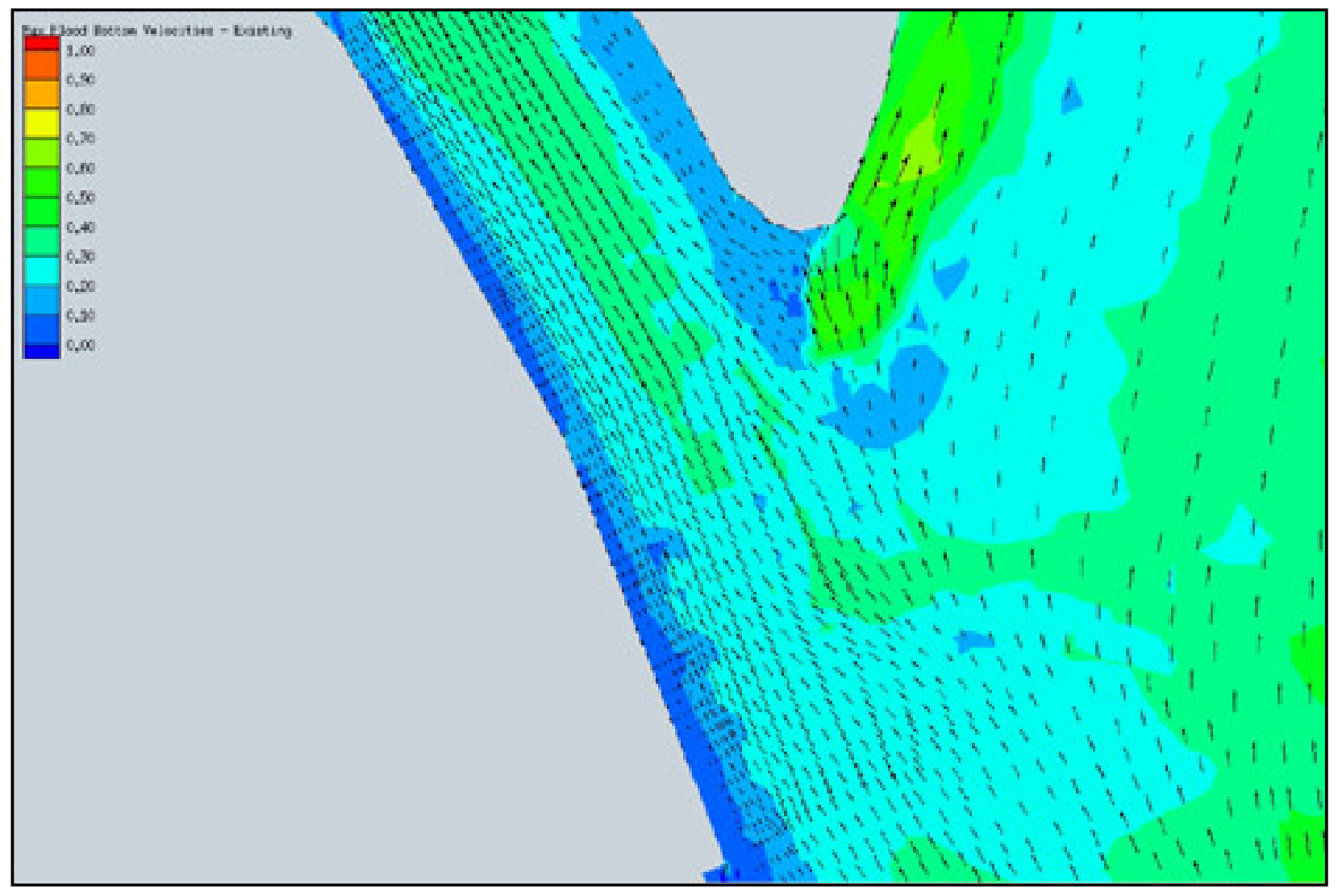

Figure 21. Near-bottom maximum flood current vectors and speed contours in $\mathrm{m} / \mathrm{sec}$ for the existing condition 


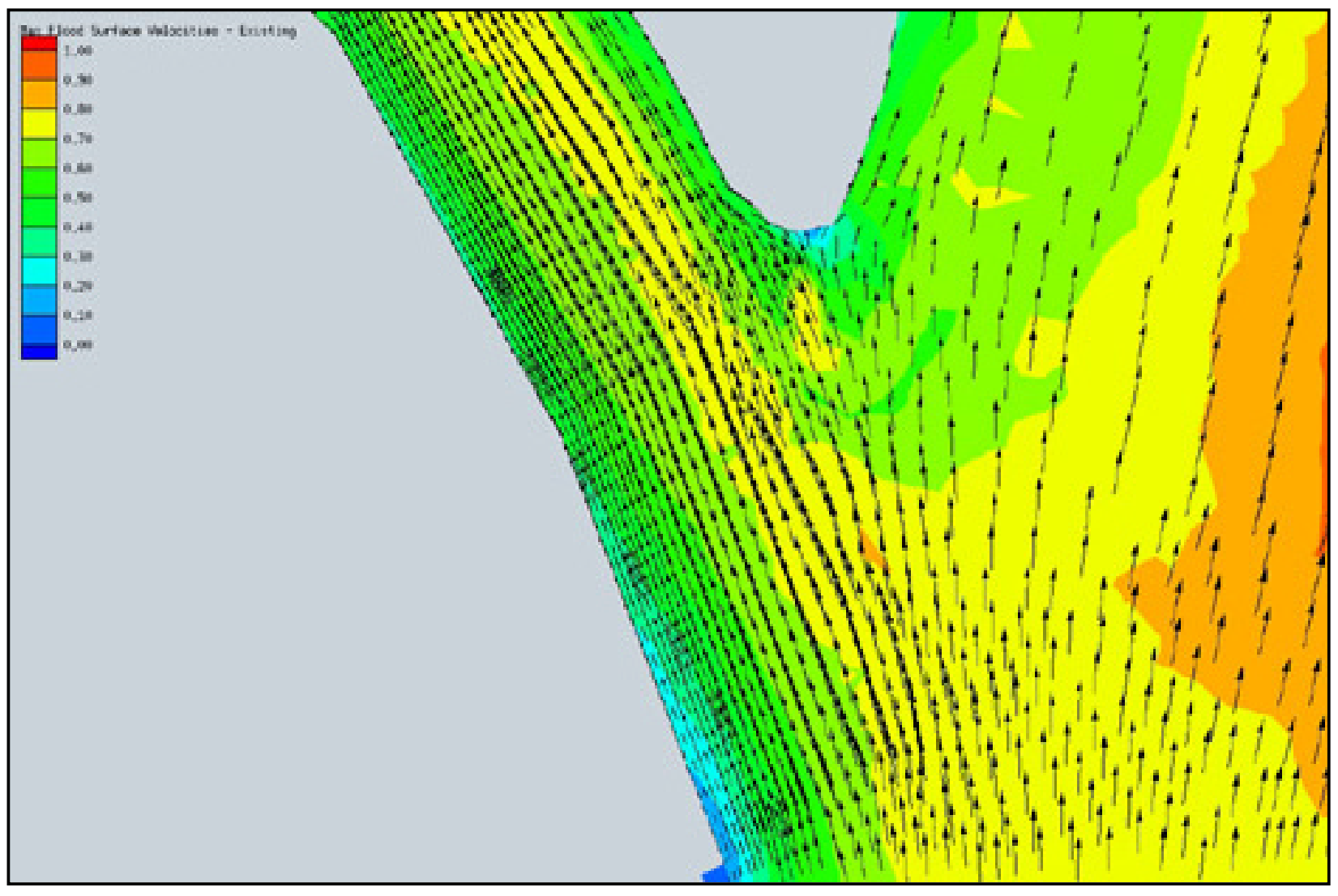

Figure 22. Surface maximum flood current vectors and speed contours in $\mathrm{m} / \mathrm{sec}$ for the existing condition 


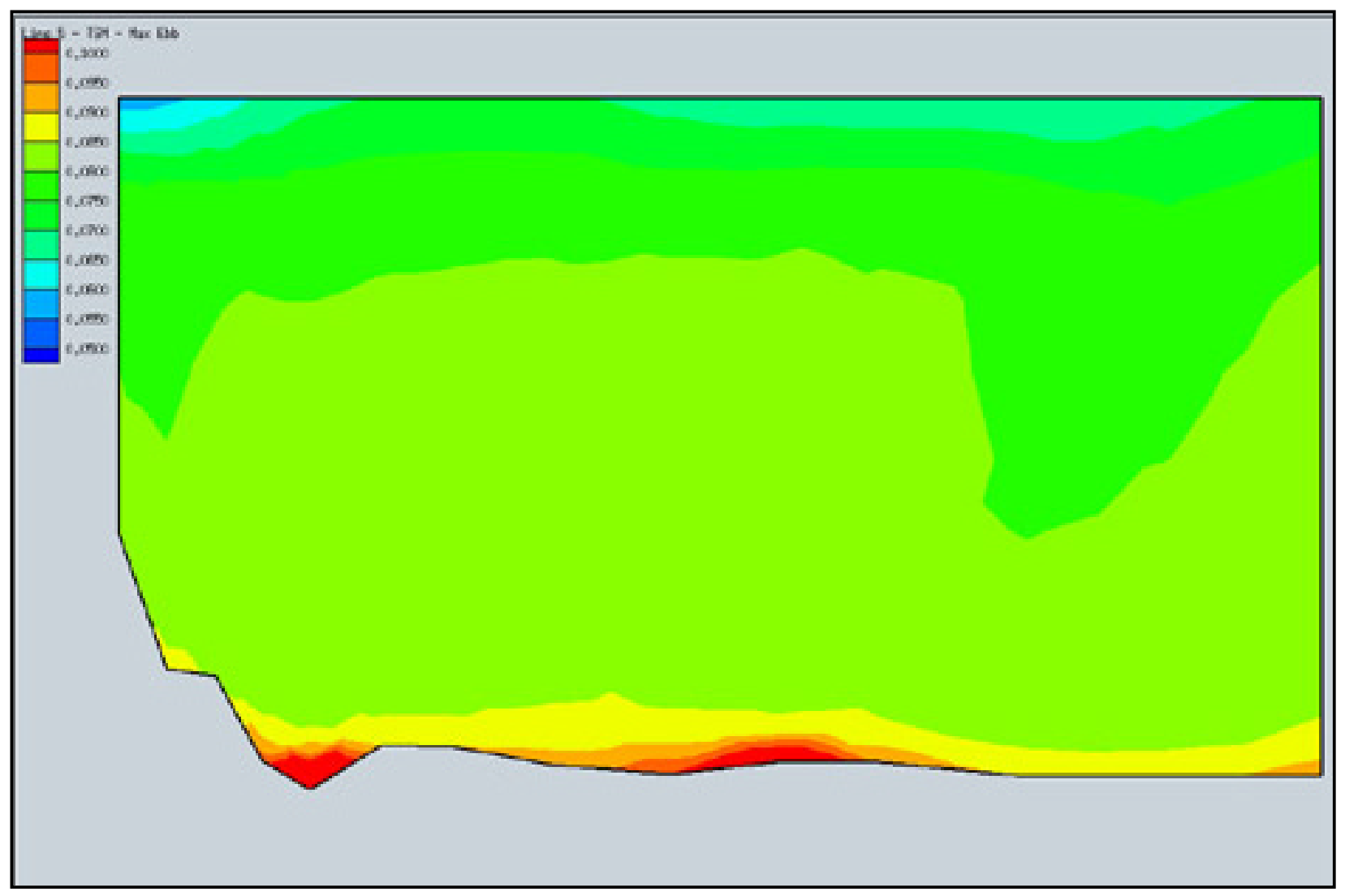

Figure 23. Vertical transect of TSM concentrations in $\mathrm{kg} / \mathrm{m}^{3}$ at maximum ebb flow for line 5 from the model 


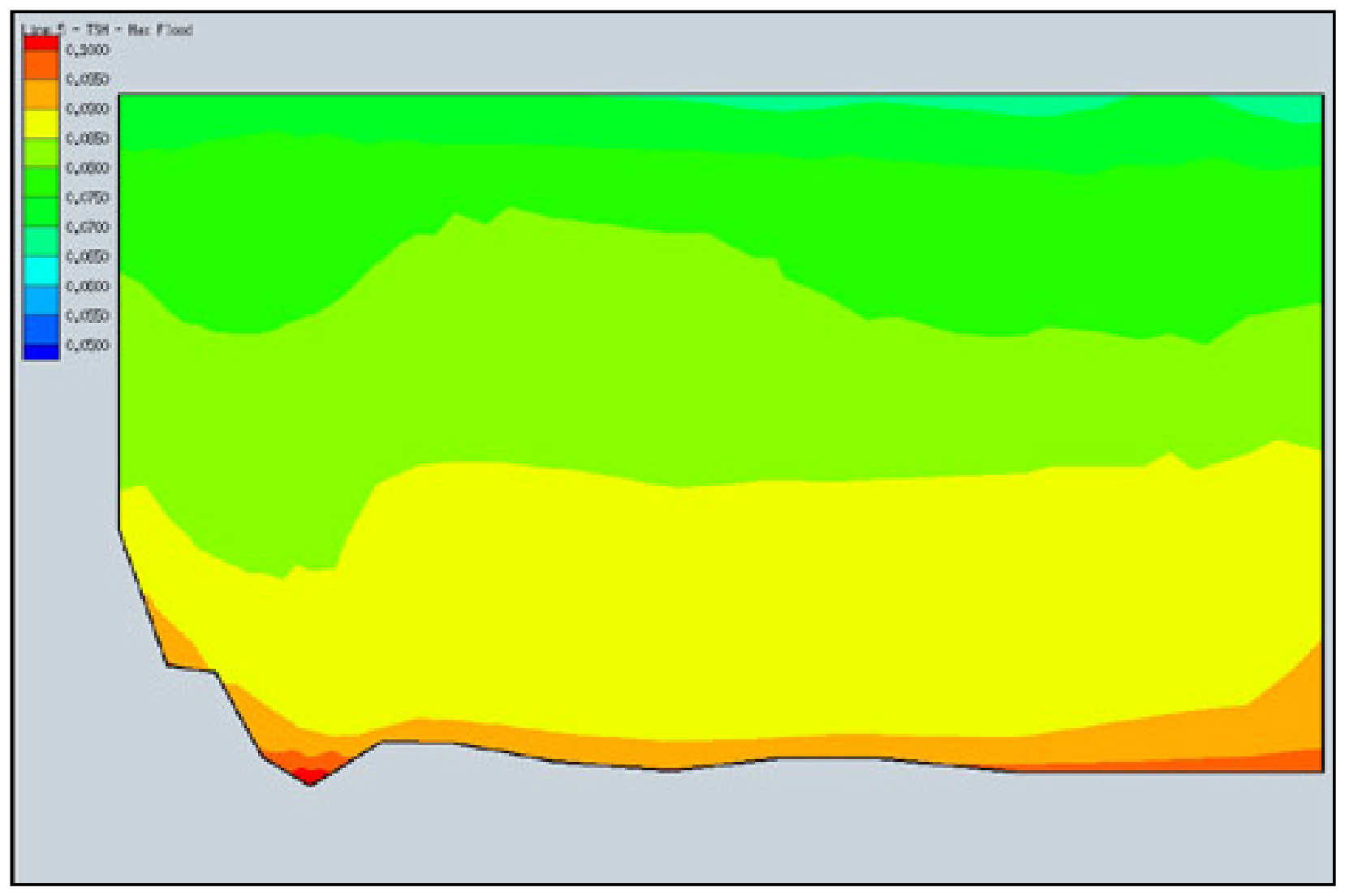

Figure 24. Vertical transect of TSM concentrations in $\mathrm{kg} / \mathrm{m}^{3}$ at maximum flood flow for line 5 from the model 


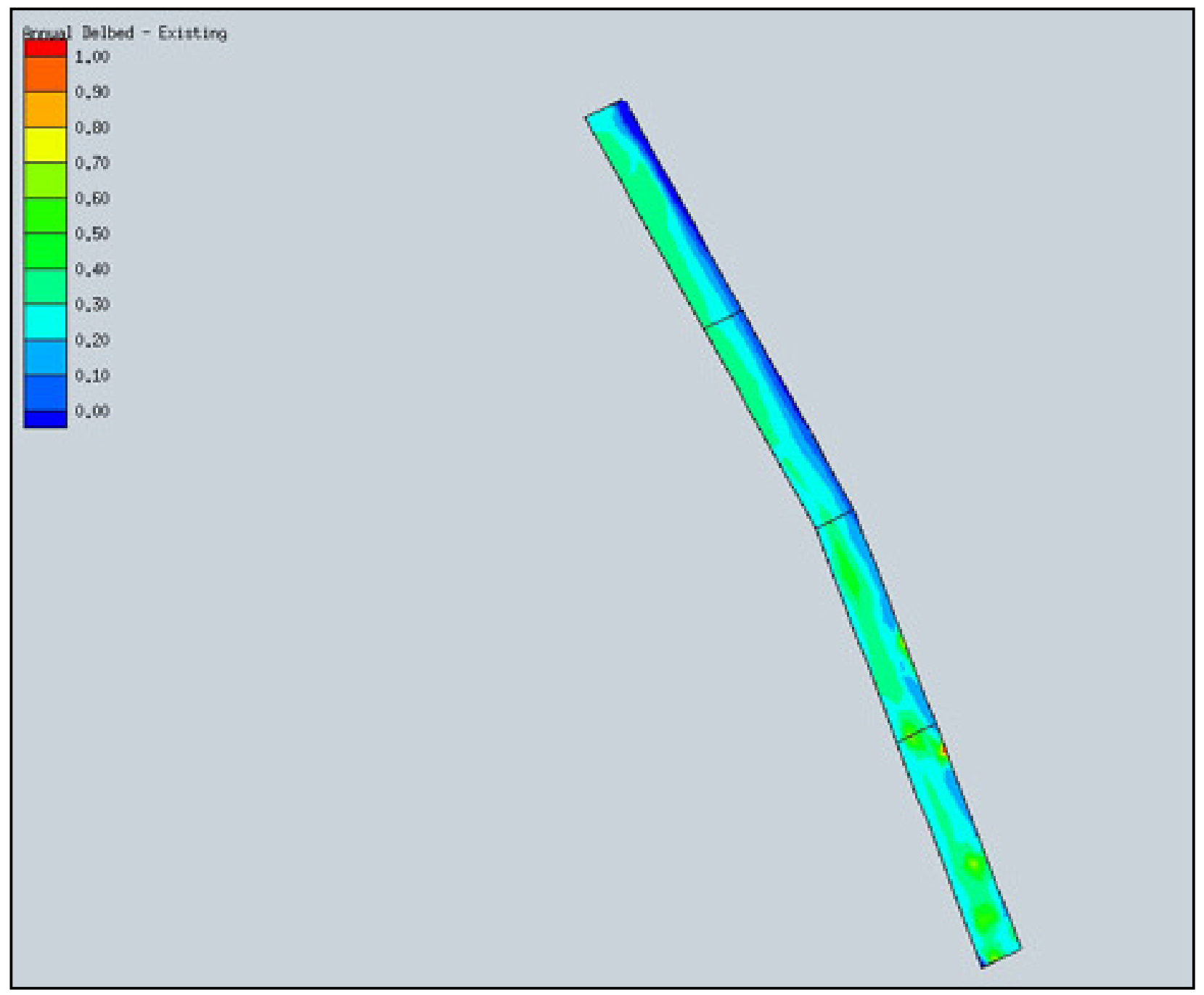

Figure 25. Change in bed elevation ( $m$, positive is deposition) for the base condition for sections $1-4$ (south to north) 


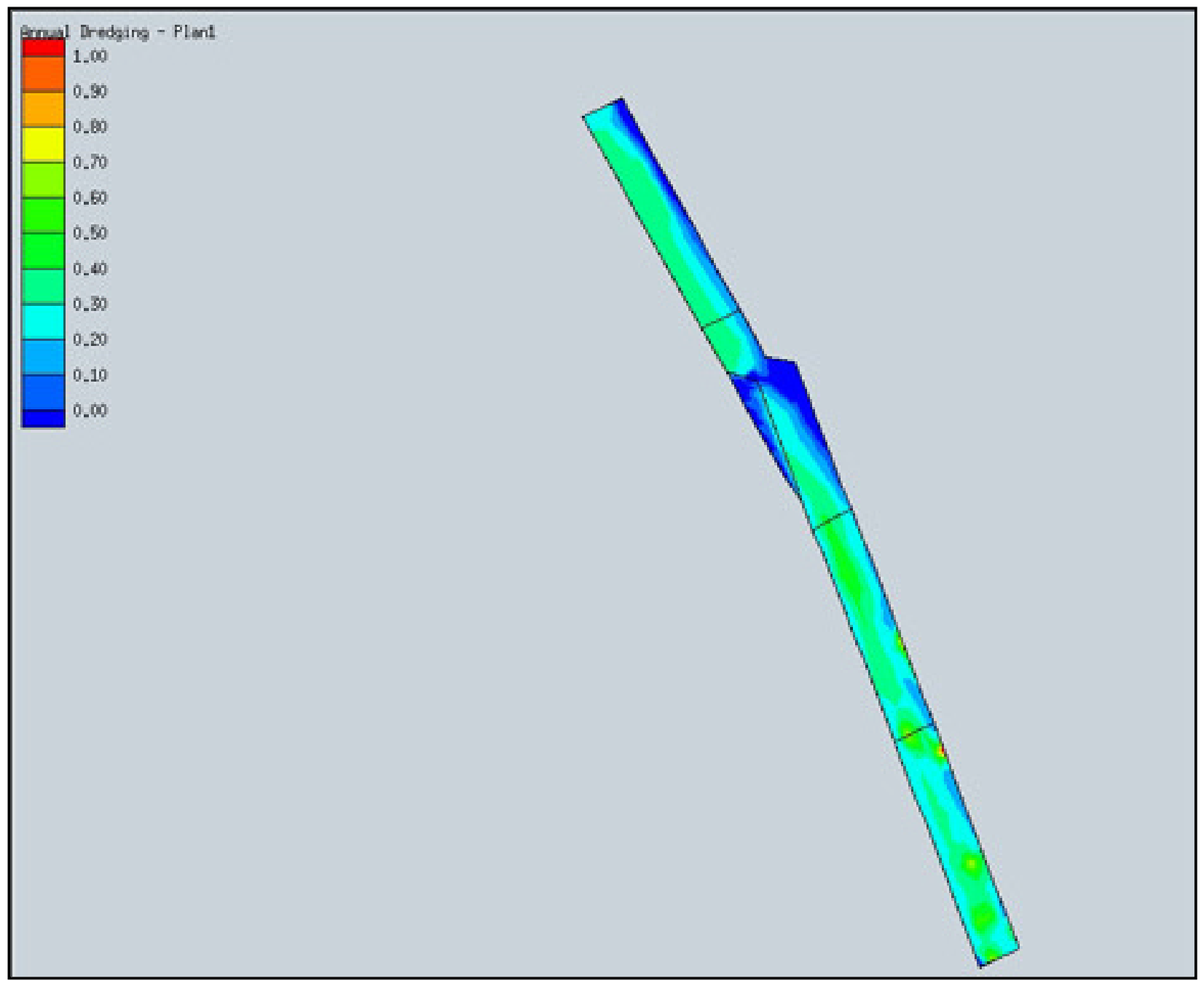

Figure 26. Change in bed elevation ( $\mathrm{m}$, positive is deposition) for the Plan 1 condition for sections 1 -4 (south to north) 


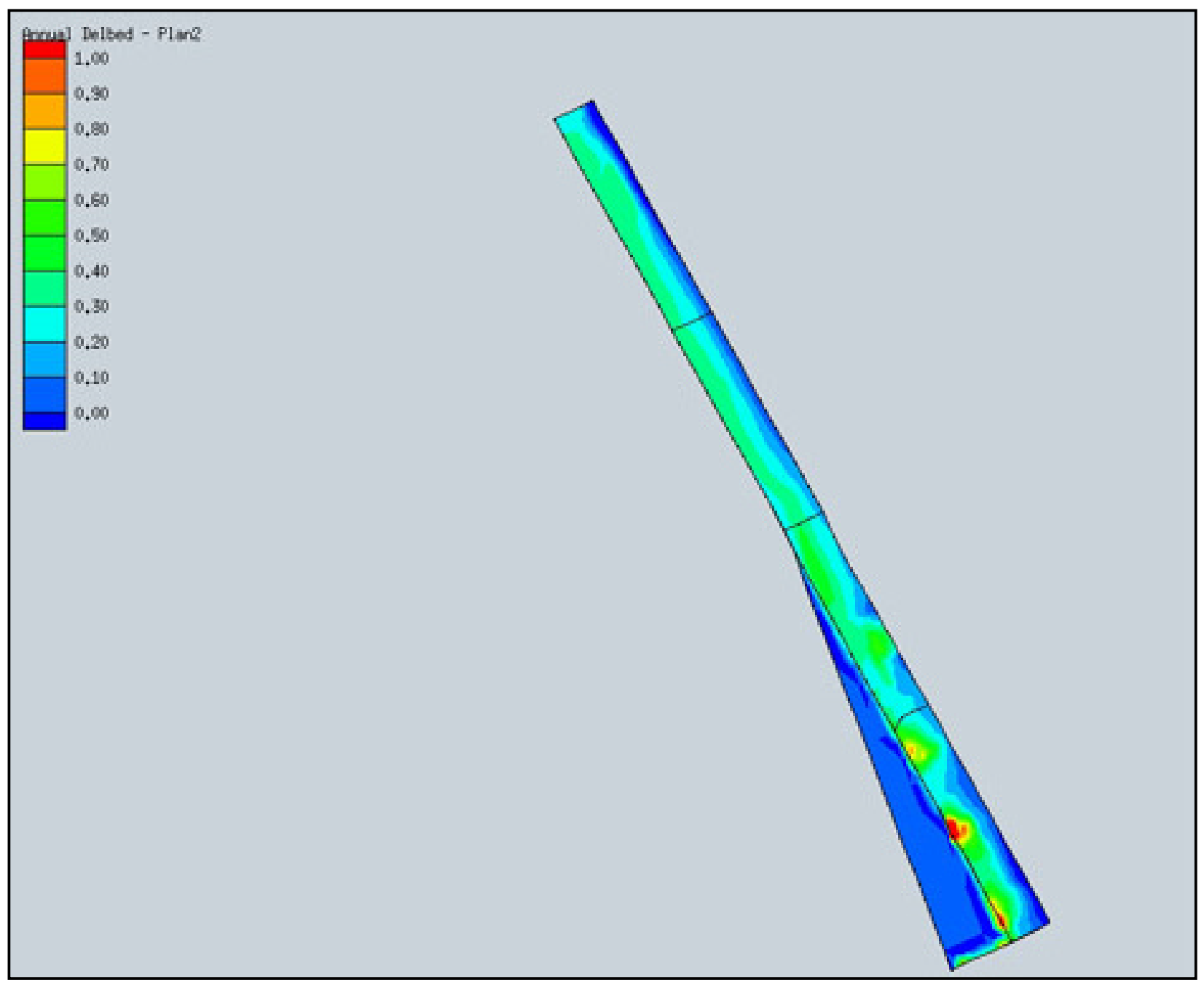

Figure 27. Change in bed elevation ( $m$, positive is deposition) for the Plan 2 condition for sections 1 -4 (south to north) 


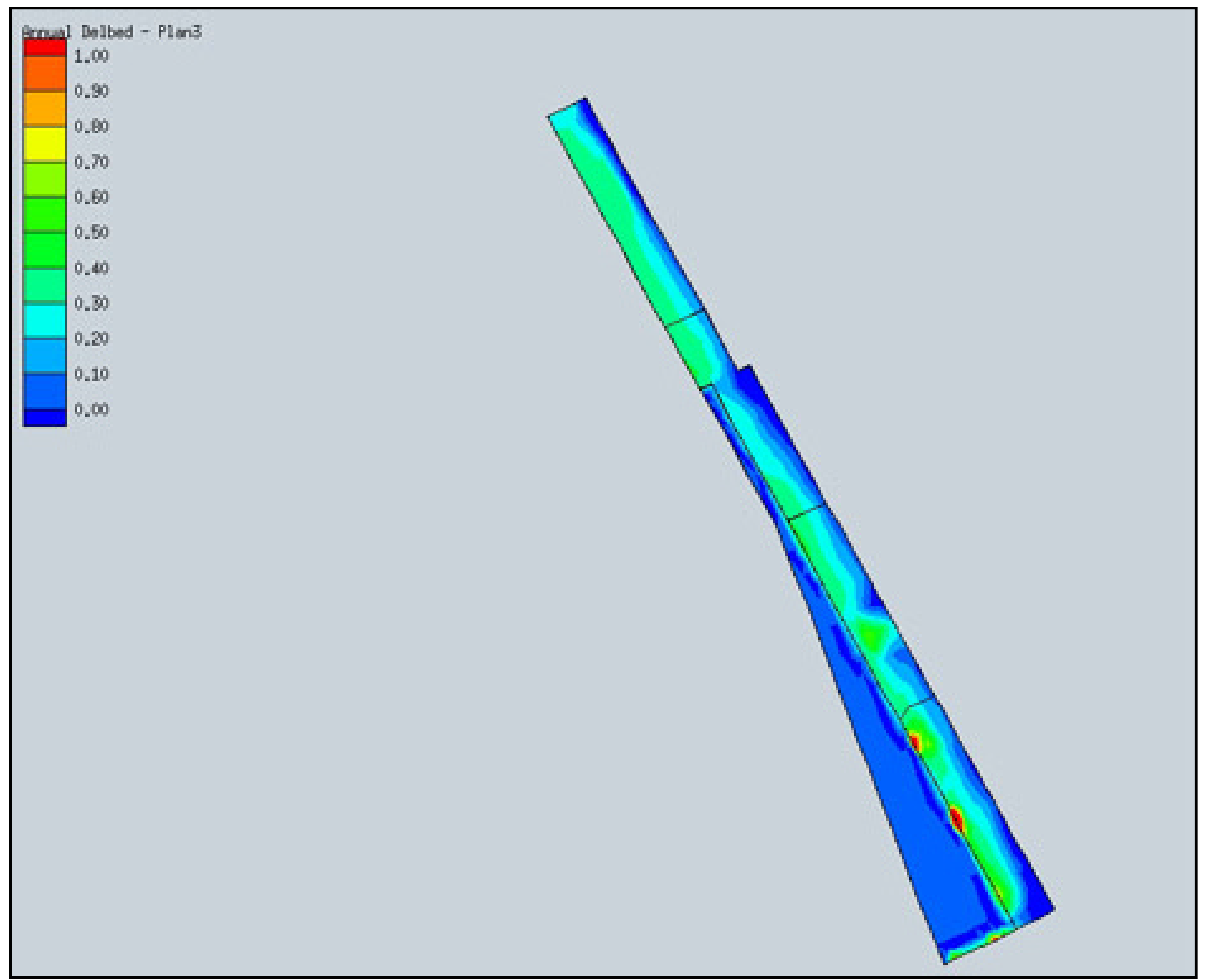

Figure 28. Change in bed elevation ( $\mathrm{m}$, positive is deposition) for the Plan 3 condition for sections 1 -4 (south to north) 
Public reporting burden for this collection of information is estimated to average 1 hour per response, including the time for reviewing instructions, searching existing data sources, gathering and maintaining the data needed, and completing and reviewing the collection of information. Send comments regarding this burden estimate or any other aspect of this collection of information, including suggestions for reducing this burden, to Washington Headquarters Services, Directorate for Information Operations and Reports, 1215 Jefferson Davis Highway, Suite 1204, Arlington, VA 22202-4302, and to the Office of Management and Budget, Paperwork Reduction Project (0704-0188), Washington, DC 20503.

\begin{tabular}{|l|l|l|l}
\hline 1. AGENCY USE ONLY (Leave blank) & 2. $\begin{array}{l}\text { REPORT DATE } \\
\text { September } 2000\end{array}$ & $\begin{array}{l}\text { 3. } \\
\text { REPORT TYPE AND DATES COVERED } \\
\text { Final report }\end{array}$
\end{tabular}

\section{TITLE AND SUBTITLE} September 2000

5. FUNDING NUMBERS

Sedimentation Response to Wharf Expansion Plans for the Columbus Street

Terminal, Charleston, South Carolina

\section{AUTHOR(S)}

Allen M. Teeter, Gary L. Brown, Christopher J. Callegan, Darla C. McVan, M. Soraya Sarruff

\section{PERFORMING ORGANIZATION NAME(S) AND ADDRESS(ES)}

U.S. Army Engineer Research and Development Center

Coastal and Hydraulics Laboratory

3909 Halls Ferry Road, Vicksburg, MS 39180-6199

8. PERFORMING ORGANIZATION REPORT NUMBER

ERDC/CHL TR-00-22

9. SPONSORING/MONITORING AGENCY NAME(S) AND ADDRESS(ES)

10. SPONSORING/MONITORING South Carolina State Ports Authority AGENCY REPORT NUMBER

P.O. 22287

Charleston, SC 29413-2287

11. SUPPLEMENTARY NOTES

\section{2a. DISTRIBUTION/AVAILABILITY STATEMENT}

12b. DISTRIBUTION CODE

Approved for public release; distribution is unlimited

13. ABSTRACT (Maximum 200 words)

Field information on currents, suspended sediment concentrations, and bed material properties was collected in the vicinity of the Columbus Street Terminal, Town Creek Lower Reach, Charleston Harbor, SC. An existing three-dimensional finite-element numerical hydrodynamic and sediment transport model was modified to provide greater spatial resolution in the study area, checked against field data, and operated to predict the sedimentation response which would result from the offshore expansion of the terminal wharf. Bed sediment near the wharf were clayey, sandy silts with densities of about 1,200 wet-kg/m $\mathrm{m}^{3}$. Sediment grain size and bulk wet density generally increased with distance off the wharf and upstream. Acoustic Doppler current profiles indicated that near-bottom currents converged toward the wharf, especially on flood-tidal phase. Appreciable vertical gradients were observed in suspended sediment concentration fields. The proposed expansion plans would move the wharf face closer to the channel center line. The numerical model predicted a modest improvement in the sedimentation along and $46 \mathrm{~m}$ out from the wharf face.

14. SUBJECT TERMS Charleston Harbor Cohesive sediment transport Estuarine hydrodynamics
Shoaling

TABS-MDS

Wharf
15. NUMBER OF PAGES 45

16. PRICE CODE
17. SECURITY CLASSIFICATION OF REPORT UNCLASSIFIED
18. SECURITY CLASSIFICATION OF THIS PAGE UNCLASSIFIED
19. SECURITY CLASSIFICATION OF ABSTRACT 